\title{
Mulemba
}

Revista Angolana de Ciências Sociais

5 (10) | 2015

Angola 40 anos de independência: memória, identidades, cidadania e desenvolvimento

\section{A transculturação de Silva Porto na África Central - Viyè - Século XIX}

The transculturation of Silva Porto in Central Africa - Viyè - $19^{\text {th }}$ Century

Constança do Nascimento da Rosa Ferreira de Ceita

\section{(2) OpenEdition}

Journals

Edição electrónica

URL: http://journals.openedition.org/mulemba/1929

DOI: $10.4000 /$ mulemba. 1929

ISSN: 2520-0305

Editora

Edições Pedago

\section{Edição impressa}

Data de publição: 1 novembro 2015

Paginação: 185-232

ISSN: 2182-6471

Refêrencia eletrónica

Constança do Nascimento da Rosa Ferreira de Ceita, «A transculturação de Silva Porto na África Central - Viyè - Século XIX», Mulemba [Online], 5 (10) | 2015, posto online no dia 11 outubro 2018, consultado o 26 janeiro 2021. URL: http://journals.openedition.org/mulemba/1929 ; DOI: https:// doi.org/10.4000/mulemba.1929 


\title{
A transculturaçãa de Silva Porto na África Central - Viyè - Século xIx
}

\section{Constança do Nascimento da Rosa Ferreira de Ceita}

\begin{abstract}
Resumo: O estudo do fenómeno da transculturação tem encontrado um vasto terreno de análise na África central. De acordo com Fernando Ortiz, a transculturação é um fenómeno entendido como a transição de uma cultura para outra, ocorrendo a perda ou o desligamento parcial da cultura precedente (cf. IzNAGA 1982: 16-19). É a partir de tais pressupostos que o autor cubano formula uma base teórica sobre a transculturação ocorrida entre várias culturas decorrentes do meio social. Com o presente trabalho, procuramos equacionar a nossa pesquisa no âmbito dos processos resultantes do entrelaçamento entre várias culturas em contacto, em pleno meio histórico e sociocultural ovimbundu, no Planalto Central de Angola, num contexto espacial da África central. Decorrentes dos vários contactos aí estabelecidos, essa diversidade cultural deu lugar a identidades múltiplas.

O fenómeno da transculturação estudado, desenvolveu-se no segundo quartel do século XIx. A complexidade e abrangência do mesmo, conduziram-nos a uma abordagem centrada na história biográfica do sertanejo português, António Francisco Ferreira da Silva Porto - um personagem que do ponto de vista histórico ficou mais conhecido por Silva Porto -, com particular incidência sobre o seu envolvimento no meio socio-cultural ovimbundu (1839-1890).

Neste artigo, procuramos analisar o itinerário de interacção socio-cultural entre o sertanejo e a sociedade ovimbundu, realçando o relacionamento intercultural, a história das relações sociais e transculturais operadas entre este e a referida sociedade que o acolheu em 1839. Desse relacionamento intercultural constituiu-se uma importante «zona de contacto», que consideramos
\end{abstract}

* O texto deste artigo constitui uma síntese que resulta da minha tese de doutoramento em Estudos Africanos na especialidade Estudos de Cultura, que produzi sob a orientacão do Professor Doutor Paulo Jorge Fernandes, co-orientada pelo Professor Doutor Elikia Mbokolo e foi defendida no dia 15 de Junho de 2015, na Faculdade de Ciências Humanas e Sociais da Universidade Nova de Lisboa. O mesmo foi elaborado por convite do Director e do Editor desta revista, para os quais expresso a minha maior gratidão.

Historiadora, é Professora Auxiliar do Departamento de História (DH) e do curso de Comunicação Social da Faculdade de Ciências Sociais (FCS) da Universidade Agostinho Neto (UAN), sendo docente das cadeiras de História de Angola, História de África e História política, económica e social de Angola do curso de História. 
muito justamente como a zona de convivência socio-política, económica e cultural. A este propósito, a historiadora Mary Pratt, que reflectiu e inovou sobre a expressão "zonas de contacto», definiu-o como espaços sociais onde culturas diferentes se encontram, chocam e aprendem a lidar uma com a «outra», quase sempre em relações assimétricas (cf. PratT 2005: 4).

Nesta conformidade, a síntese do nosso trabalho reflecte a problemática de cultura africana, particularmente ovimbundu em Angola e, em geral, na África central, a partir do confronto entre a cultura europeia e a cultura africana, particularmente portuguesa e ovimbundu, sobretudo. Trata-se, enfim, de um estudo histórico-antropológico articulado sobretudo a partir de quatro variáveis: o casamento poligínico, a alimentação, o comércio e a religião, variáveis essas que, em nosso entender, viriam a determinar a transculturação do sertanejo português na África central.

Palavras-chave: Transculturação, aculturação, alteridade, história de vida, zona de contacto intercultural, Angola, África central.

\section{Introdução}

Neste trabalho debruçamo-nos sobre o estudo da transculturação que é entendida como a transição de uma cultura para outra, ocorrendo a perda ou o desligamento parcial da cultura precedente, de acordo com as premissas de Fernando Ortiz (1983). ${ }^{1}$ O fenómeno da transculturação desenvolveu-se em Angola, mais exactamente no meio socio-cultural ovimbundu, a partir do segundo quartel do século xIx. A complexidade e abrangência do fenómeno conduziram-nos para uma abordagem centrada na história de vida do sertanejo português, António Francisco Ferreira da Silva Porto, que na história de Angola ficou mais conhecido como «Silva Porto», com particular

1 Cf. Iznaga (1982). Neste breve artigo, publicado na revista Bohemia em 25 de Junho de 1982, Diana Iznaga analisa a biografia do antropólogo cubano Fernando Ortiz, destacando o papel da sua pesquisa no domínio dos processos resultantes do entrelaçamento entre várias culturas diferentes, decorrentes do meio social. Essa diversidade cultural forma identidades através dos vários contactos estabelecidos, porque cada cultura dá sempre algo de novo à outra cultura, havendo uma perda de elementos, mas há também introdução de novos elementos, formando um câmbio cultural. Ortiz, parte mesmo da experiência do seu próprio país, Cuba, que é um vasto terreno transcultural e a partir daí formula uma base teórica sobre a transculturação. Entretanto, Lívia Reis, que traduziu em 1983 o artigo de Fernando Ortiz, «Del fenómeno de la "transculturación" y de su importância em Cuba», viria a propôr que o termo «transculturação» substituisse, ainda que parcialmente, um outro termo que geralmente era usual: a aculturação. Assim, o término transculturação apresenta-se hoje como um neologismo que é entendido para expressar a diversidade de fenómenos culturais que se vêm desenvolvendo ao longo dos tempos, que pode ser aplicado nos diversos ramos da ciência e, por isso mesmo, nós o utilizamos neste estudo histórico-antropológico. Ver igualmente Iznaga (1989). 
incidência para o seu envolvimento no meio sociocultural ovimbundu, em Angola (1839-1890). Analisamos aqui o itinerário de interacção socio-cultural entre Silva Porto e a sociedade ovimbundu, destacando o relacionamento intercultural, a história das relações sociais e transculturais operadas entre esse personagem e a referida sociedade, que o acolheu desde 1839. Esse relacionamento intercultural, constituiu-se numa importante «zona de contacto», considerada zona de convivência socio-político-económica e cultural (PRATT 2005: 4). ${ }^{2}$ Mary Pratt, inovou o termo «zonas de contacto», para o definir como espaços sociais onde culturas diferentes se encontram, chocam e aprendem a lidar com o "outro», quase sempre em relações assimétricas de dominação e subordinação, como o colonialismo, a escravatura ou suas consequências, e como são vividas no mundo actualmente.

É um estudo sobre a transculturação proporcionado por um diálogo com a História e a Antropologia, onde afirma que «ninguém é apêndice da sua cultura». A autora questiona sobre essas zonas de contactos observadas no passado e no presente e tendentes a poder ocorrer futuramente, constituindo-se como espaços de violência, reconciliação e/ou co-existência. Aborda os tipos de violência, as suas causas, o processo de formação, as mudanças, e como estes se relacionam com a justiça social ou em resistência a esta. Silva Porto foi uma consequência dessa articulação na zona de contacto ovimbundu, foi actor interactivo entre o global e o local, foi o resultado de uma migração, do tráfego comercial, cultural e de várias formas de hibridismo, provocando a diáspora no global com o tráfico de escravos, com o bilinguismo entre umbundu e português, com a mestiçagem na sua família luso-angolana. Assim, parece-nos comum poder identifica-se em Silva Porto uma história social e transcultural a três escalas: a escala biográfica da sua própria vida, a da sociedade ovimbundu e, em geral, a da sociedade africana.

Em 1829, Silva Porto emigrou de Portugal para o Brasil, e dali para Angola, em 1838. Em 1839, após uma curta estadia em Luanda, lançou-se numa viagem pelo interior da África central. Começou por

2 O estudo de Mary Pratt foi traduzido e publicado no Brasil com o título Os olhos do Império: relatos de viagem e transculturação (2005). Trata-se de um estudo sobre as interações interculturais claramente definidas, que foi apresentado inicialmente na conferência intitulada $O$ «Contact Zone» revisitado: violência, reconciliação e co-existência, organizada pela Universidade de Wisconsin, Madison, nos Estados Unidos da América (USA), em Abril de 2001. 
se integrar numa caravana comercial que tomou rumo em direcção à linha de penetração do rio Kwanza, passando pelas localidades do Dondo, Lukala, Mpungu a Ndongo, Kasanji, Musende, acabando esse périplo por terminar no Viyè, onde residiu durante 50 anos. ${ }^{3}$ De 1841 a 1857 realizou viagens a vários pontos da África central: ao Barotse, seguindo o curso dos rios Lutembo e Lyambezi, Katongo (Lwi) e no Kuchi (Zâmbia), abrindo o comércio, permutando produtos europeus por africanos: escravos, marfim, cera e urzela (goma copal). As rotas comerciais de Silva Porto difundiram-se por três zonas na África central: A primeira para o Nordeste e Leste no império Lunda na Musumb (capital), Katanga, Kasayi ocidental, Kuba, Moyo, nas margens dos rios Lwembe, Kwangu, Lwalaba, Lwiza, Lubilachi, por ser o mercado mais forte de escravos e de marfim, que negociara com Mwant Yanv (soberano Lunda), na que é hoje a República Democrática do Congo (RDC). A segunda rota foi para o Leste e Sudeste: Kazombo, Kwitu, Kwanavale, Kuci, Kuvangu, Lwi e Katanga (actualmente situa-se na RDC), e para o Ocidente, Litoral Sul: Wambu, Kakonda, Kilenge, Katumbela, Bengela) em Angola.

Na pesquisa bibliográfica realizada, não foram encontrados estudos sobre o fenómeno de transculturação em África e, particularmente, em

3 Localidade onde Silva Porto fundou a sua «aldeia», que a designou Belmonte. $O$ Viyè, que na sua origem constituia um espaço e unidade territorial dirigido por um Osoma, com a implantação portuguesa passou a ser um entreposto comercial para vários pontos de África central e austral, de onde partia a maioria das caravanas comerciais desde o século XvIII, dirigidos por grupos de sertanejos veteranos, já que, desde 1791 que aí já se fazia sentir a autoridade portuguesa. Em 1848, numa das viagens que o Major Francisco José Coimbra efectuou ao Cubango (isto é, Kuvangu), na região ngangela (Sudeste de Angola), este encarregou Silva Porto da chefia do governo do distrito, tendo sido indigitado capitão-mor do Bihé [Viyè] e Bailundo [Mbalundu], pelo governador João de Reboredo, em 30 de Maio de 1848. Nessa altura, Silva Porto teve como primeira acção reunir-se com os sertanejos e os feirantes portugueses, contra a resistência do soberano do Viyè, o Osoma Riyambulla, também conhecido por D. António Lencastre. Posteriormente, Silva Porto viria a ser nomeado oficialmente capitão-mor do Bihé e Bailundo, por Portaria provincial n. ${ }^{\circ}{ }^{174}$, de 3 de Abril de 1885, pelo governador-geral de Angola, Ferreira do Amaral, quando este já era septuagenário e contava cerca de 46 anos de vivência no seio na sociedade umbundu. Segundo alguns autores, Libata significa, na língua kimbundu, «vila residencial de um chefe local», "acampamento considerado como aldeia»; Osoma (plural: olosoma), é um título político de uma entidade máxima da hierarquia política, social e cultural da sociedade umbundu. Viyè, que apareceu sempre grafado em português Bihé, e depois Bié, é o designativo vernáculo do lugar e reino com esse nome e que hoje dá nome a uma das províncias de Angola. 
Angola. Fundamentalmente, a problemática aqui levantada visou saber quem é Silva Porto, após ter permanecido 50 anos em Angola, num meio bastante diferente do seu, distante, numa imensidão de saberes, povos, e culturas diferentes. Foram esses dados transcritos no seu Diário de viagens, que nos impulsionou a aprofundar o entendimento sobre o fenómeno da transculturação de Silva Porto na África central e em particular em Angola.

\section{O envolvimento de Silva Porto na sociedade ovimbundu}

Silva Porto chegou ao Viyè em 1840. Aí encontrou uma grande solidariedade entre os comerciantes da praça viyena e o apoio da família do Major Francisco José Coimbra, que o colocou em contacto com a corte do Viyè. $\mathrm{O}$ desenvolvimento desta convivência permitiu-lhe criar laços de amizade com os membros da corte que, por sua vez, facilitou o acesso às autoridades no Ekovongo, antiga capital do Estado de Viyè, com vista à concessão de um espaço, a fim de se instalar, mediante a celebração de um pacto de fidelidade. É com base em suas pretensões, que a corte o autorizou que se fixasse nas margens do rio Kwitu, num lugar situado há pouco mais ou menos 10 quilómetros de Ekovongo. Quando aí se instalou, Silva Porto integrava a segunda geração de sertanejos do Viyè.

Em 1841, Silva Porto funda assim um grande acampamento, que este a designou libata. No entanto, na língua local, um ajuntamento residencial desse tipo é geralmente mais conhecido por imbo. Mais tarde, este atribuíu-lhe o nome de Belmonte. Mas os naturais baptizaram-na de Ombala ya Mpoloto, sendo Mpoloto uma corruptela do nome Porto. Ombala significa capital, centro da aldeia de um grande senhor, de um soberano. Atribuíram o designativo de ombala a esse acampamento por Silva Porto imitar, simbolicamente, a estrutura de uma sede política do soberano do Viyè. O termo liba$t a$, introduzido por Silva Porto não é português, provém da língua kimbundu, que significa «aldeia». Silva Porto designou o acampamento por aldeia pois tinha consciência que o seu acampamento de Belmonte não se enquadrava nos moldes da estrutura administrativa do Estado de Viyè.

A libata de Belmonte estava situada na parte mais elevada de um outeiro constituindo um ponto estratégico, cuja vertente norte 
descia suavemente em direcção ao leito do rio Kwitu, que corre a leste para o rio Kukema.

Figura 1. Gravura da ombala de Silva Porto nas imediações do rio Kwitu

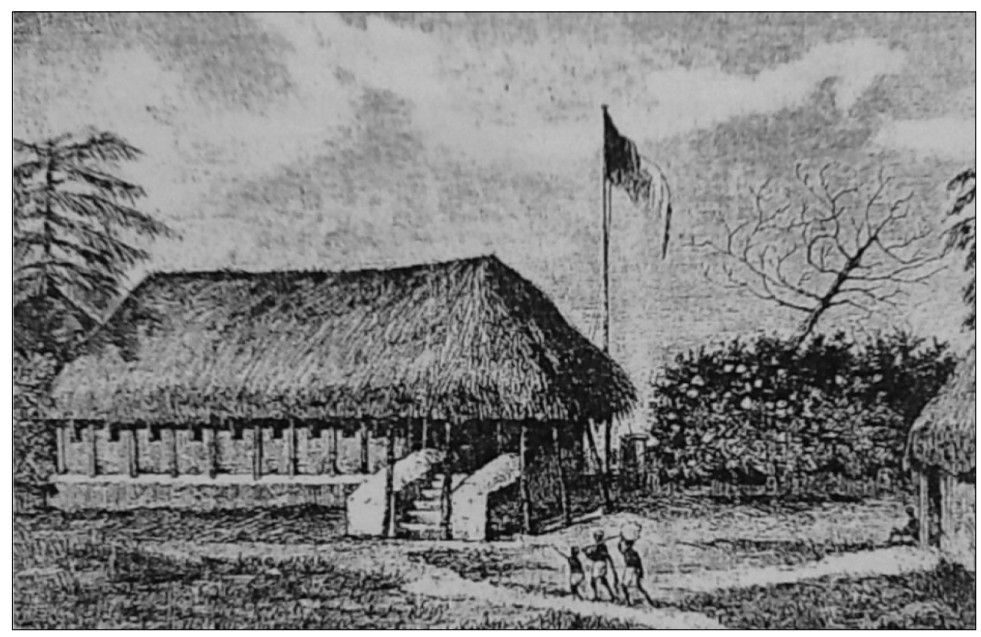

Fonte: Desenho de Serpa Pinto, publicado em 1902.

Durante esta fase decisiva da sua instalação no Viyè, Silva Porto viu-se confrontado por várias entidades locais, que bloquearam as suas actividades sertanejas: Mbandwa II e Njamba yà Mina, soberanos do Viyè, foram considerados por Silva Porto, como grandes olosoma, protectores da povoação: «uns povoam e outros despovoam, é a história do geral dos sobas que habitam o continente africano» (PoRTo cf. Manuscrito, vol. XI). Aliado ao seu projecto de fixar-se no interior, ele é orientado por um antigo sertanejo, António Pacheco Osório, como símbolo da solidariedade entre os emigrantes sertanejos antigos e os novos. Silva Porto retorquia: «Eu 190 disse que o poder dos portugueses no continente africano tem custado rios de dinheiro e sangue a jorros a esta verdade que não cessarei de apregoar [...] respeitem e lhe prestem homenagem a fim da nossa sociedade seja de irmãos» (PorTo idem). Nesse sentido, a administração colonial começou por criar estruturas económicas e político-militares capazes de proteger os europeus emigrantes, comerciantes, sertanejos, que surgiam dentro deste sistema, servindo de pontas de lança para a actividade colonizadora. A maioria dos portugueses, imigrantes individuais à margem do governo, viria a 
integrar batalhões de cavalaria, com treinos militares. Foi no período de 1842, que Silva Porto se associou ao grupo de cerca de 200 sertanejos, que fixaram residência na praça comercial do Viyè. $\mathrm{O}$ grupo de sertanejos criou aí condições para se estabelecerem para uma vida mais sedentária, e formaram um centro de união no chamado njango de Amarante, situado próximo da capitania-mor, uma espécie de colonato, e aí fundaram uma escola, uma igreja e um hospital.

Os sertanejos criaram redes comerciais e, desse modo, caravanas comerciais acorriam às feiras munidos de diversos produtos manufacturados oriundos da Europa, de Luanda e de Bengela, sobretudo fazendas, para serem trocadas por cera, marfim e escravos. Uma das grandes casas abastecedoras de fazendas foi a de D. Ana Joaquina dos Santos Silva que, nessa época, tinha estabelecido estreitas relações comerciais com Silva Porto, através do seu sócio Francisco Rodrigues Graça, que tinha permanecido no Viyè no período de 1843 a $1846 .^{4}$

Trata-se de um fenómeno que ocorreu na vida de Silva Porto, consubstanciado em cinco variáveis, que transformaram a sua personalidade enquanto europeu emigrante na África central, sendo a primeira variável e a principal, necessária para a sua inserção no novo meio encontrado, o seu casamento.

\subsection{O casamento de Silva Porto}

O casamento foi a primeira variável e a acção determinante para a integração de Silva Porto na sociedade ovimbundu. Com vista a sua inserção começou por contrair laços matrimoniais e, consequentemente, os seus descendentes foram directamente incluídos nessa sociedade, por filiação na linhagem matrilinear e tendo por base o estabelecimento de relações afins.

Nesta conformidade, podemos encontrar no diagrama que se segue, a constituição da sua família e o seu respectivo grau de

4 Silva Porto começou por estabelecer contactos comerciais com Senhora D. Ana Joaquina dos Santos Silva durante o período em que trabalhou em Luanda como empregado de balcão na Rua Direita de Luanda. Posteriormente, no início da sua actividade no Viyè, manteve estreita ligação com a praça de Luanda, não obstante o facto de ter lançado um programa financiador com um armador de Bengela, para a fiança dos seus produtos manufacturados. 
parentesco desde as origens em Portugal (os seus ascendentes), e, consequentemente, os seus múltiplos casamentos na África central. No entanto, neste diagrama não constam todos os seus filhos; constam, sobretudo, as mulheres e os filhos que ele mencionou no seu Diário. Entre outras alianças estabelecidas pelo sertanejo, o referido diagrama apresenta as três principais esposas.

Figura 2. Diagrama de parentesco da família de António Francisco Ferreira da Silva Porto

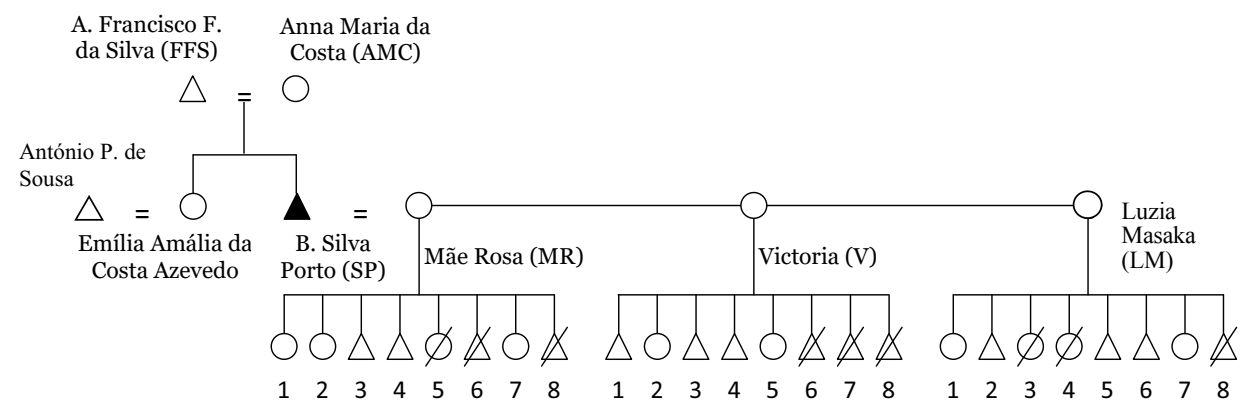

LEGENDA

$\triangle$ Indivíduo do Sexo Masculino

Indivíduo do Sexo Feminino

$\triangle$ Indivíduo Falecido

$\varnothing$ Indivíduo Falecido

$=$ Casamento

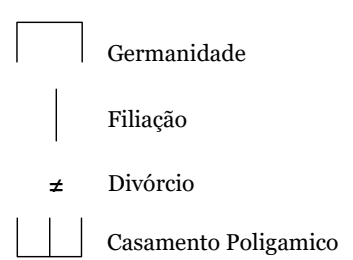

Casamento Poligamico

Da leitura deste diagrama, podemos aferir que B é Silva Porto (SP), sendo filho de A, Francisco Ferreira da Silva (FFs) e de Ana Maria da Costa (AMC) entenda-se, tendo uma única irmã, Emília Amália da Costa Azevedo, que é casada com António P. de Sousa. Pode ler-se ainda que Silva Porto (SP) contraiu casamento com três mulheres, a saber: Mãe Rosa (MR), a sua primeira esposa, nome como esta era conhecida e chamada na comunidade, com quem teve oito filhos, sendo quatro do sexo masculino e quatro de sexo feminino. Mãe Rosa era neta do osoma do Viyè, sendo oriunda do Lumbu da dinastia de Mbandwa. Foi através da celebração deste casamento que Silva Porto integrou a corte em 1841, um facto que facilitou a concessão de autorização para construir a libata de Belmonte e que tornou possível a sua instalação; e também, que o autorizou a efectuar as viagens comerciais, fazer a sua lavra, plantar um pomar 
e praticar a pastorícia nas margens do rio Kwitu. Como membro da família, Silva Porto estabeleceu a partir daí uma relação directa com a corte, tendo passado a designar a sua primeira mulher, Mãe Rosa, por «minha dona de casa».

Para os Ovimbundu, «mãe» significa a sua própria mãe biológica, mas esse termo é também classificatório, sendo geralmente utilizado em relação às outras mulheres da geração desta e às mães de toda a comunidade. Uma mulher de idade em relação às outras é também chamada de mãe por respeito. Foi a «Mãe Rosa» quem dirigiu a libata de Belmonte, tendo em suas mãos a responsabilidade da educação não apenas dos seus filhos, mas também de muitos dos outros filhos que Silva Porto teve com outras mulheres, e dos filhos originários de «olosomas» vizinhos e de sertanejos europeus que terão sido aqui acolhidos. É que, na sua residência de Belmonte, Silva Porto educou também filhos de amigos, de soberanos vizinhos e de pombeiros. A família alargada na unidade residencial de Silva Porto era um facto. É por isso que à «minha dona de casa», todos os membros lhe chamavam Mãe, tanto por cortesia quanto por respeito pela significação da descendência matrilinear nesta sociedade, mas também pela força determinante que exerceu na liderança da iniciação na vida da ombala de Belmonte. Ao longo da sua vida e do casamento com Silva Porto, Mãe Rosa viu falecerem três filhos, sendo dois rapazes e uma rapariga.

Ainda no diagrama, e na mesma sequência de B, encontramos Vitória (v), a segunda mulher de Silva Porto, que gerou oito filhos, dos quais também faleceram três, sendo todos do sexo feminino. Deste casamento, as suas filhas, Guilhermina Victória da Silva Porto, Amélia Ferreira da Silva Porto e Cecília da Silva Porto permaneceram em Bengela. A poligenia de Silva Porto foi circunstancial e inseriu-se numa estratégia de comércio, que foi a sua principal fonte de receitas no Viyè. Silva Porto fazia parte de uma família numerosa e fez deslocar quatro filhos para Portugal: Amélia, Salustiano, Narciso e Francisco. Amélia foi entregue à sua tia Emília Amália da Costa Azevedo, residente no Porto. Mais tarde, será internada no asilo de Santa Estefânia, em Guimarães, com seu irmão Salustiano, destacado aluno, que passados alguns anos faleceu vítima de varíola, em 8 de Outubro de 1882. Amélia é a filha que foi internada no colégio de São José em Benfica e, mais tarde, no prestigiado colégio Van Haffe (CoRDEIRO 1890: 20). Narciso e António foram enviados em 1859 para casa de 
seus parentes em Portugal e dali para o asilo de Santa Estefânia. Ambos faleceram por doença. António faleceu a 27 de Setembro de 1870 no «asylo de Santa Estefânia» em Guimarães. ${ }^{\mathbf{5}}$

Finalmente, encontramos no diagrama uma terceira e última mulher, Luzia Masaka (LM), que teve também oito filhos, sendo quatro do sexo masculino e quatro do feminino. Tal como as anteriores, LM viu também falecerem três filhos, sendo um do sexo masculino e duas do sexo feminino.

O Diário de Silva Porto revela que além dos filhos das três mulheres apontadas pelo diagrama, este teve outros filhos nascidos de relações extra conjugais com seis mulheres serviçais, tendo assumido a paternidade de todos eles. Da relação com a primeira serviçal nasceram dois filhos do sexo masculino, com a segunda nasceram dois do sexo masculino e uma do sexo feminino, com a terceira relação nasceram dois filhos de sexo masculino, da quarta serviçal teve uma filha, da quinta gerou três filhos do sexo masculino e da sexta gerou um casal.

Figura 3. Família Silva Porto

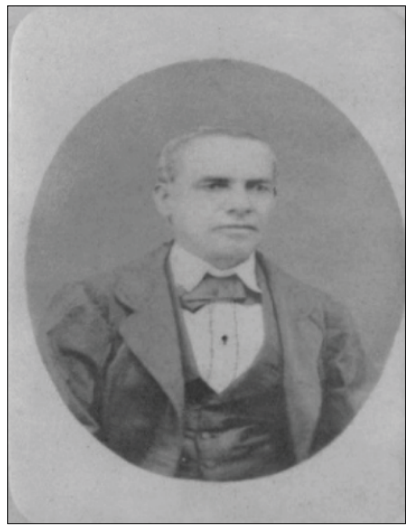

Foto de Silva Porto oferecida à SGL em 1869, durante uma curta estadia em Lisboa

Fonte: Espólio da SGL, cx. SP

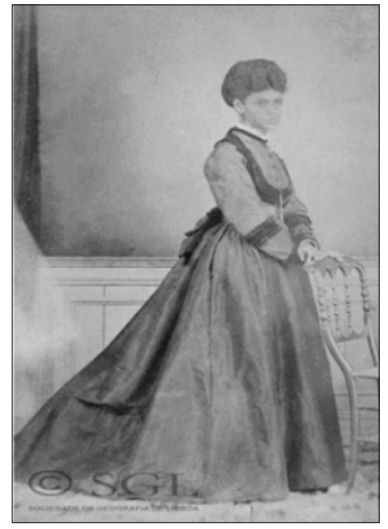

Amélia Amália da Silva Porto, filha de Silva Porto, no Colégio de São José em Benfica Lisboa, 1862

Fonte: Espólio da SGL, cx. SP.

5 Durante o período de permanência na sociedade ovimbundu, Silva Porto registou o falecimento de muitos filhos. No período de $1845^{-1863}$ em Bengela, Silva Porto sepultou, amigos, afilhados, filhos e mulheres. O sertanejo tinha o controlo de todos os filhos mas, muitas vezes, tomava conhecimento da morte de alguns deles, de forma imprevista. 


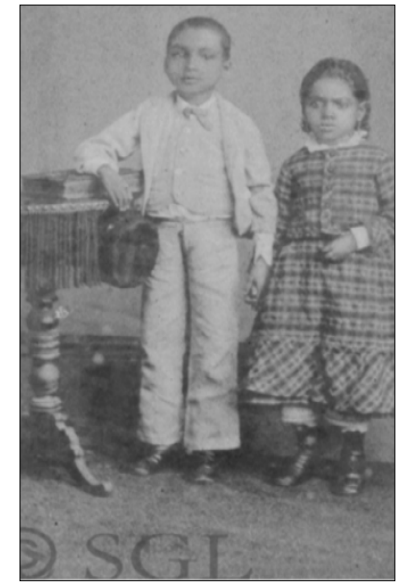

António José da Silva Porto e Amélia da Silva Porto, filhos de Silva Porto, Asilo de Santa Estefânia, Guimarães, 1882

Fonte: Espólio da SGL, cx. SP.

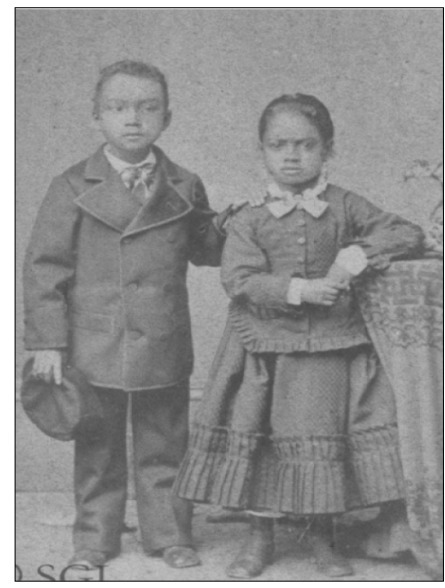

Filhos de Silva Porto, no Asilo de Santa Estefânia, Guimarães, o8/10/1876

Fonte: Espólio da SGL, cx. SP.

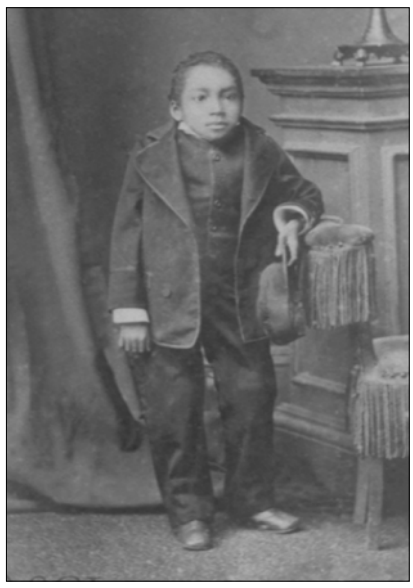

Salustiano da Silva Porto, filho de Silva Porto, Asilo de Santa Estefânia, Guimarães, 01/01/1877

Fonte: Espólio da SGL, cx. SP.

No seu processo de integração na sociedade ovimbundu, bem como nas outras áreas onde realizava as suas actividades comerciais, Silva Porto também teve filhos com várias mulheres, gerando filhos com algumas delas em diferentes áreas de África central e austral. Mulheres empregadas nas suas fazendas, domésticas da sua ombala, nos estabelecimentos, algumas das quais mais distanciadas, tais como as de Kazombo, Ngangela e Katongo (Barotse, Zâmbia). 
A maioria dos filhos de Silva Porto, tais como Amália, Clara, José, Maria, Ana, Luís, Francisco, Salustiano, Amélia, Carlos, António e Narciso, foi registada só com o sobrenome do pai «Porto». No entanto, na sociedade ovimbundu, os filhos adoptam os nomes pelas circunstâncias da vida. Será que nenhum destes filhos adoptou os nomes originários da matrilocalidade? Para nós tornou-se certo que eles também tinham esses nomes, contudo, Silva Porto ocultou-os, não se preocupou em divulgá-los, ou simplesmente, desinteressou-se. Apesar de não mencionar os nomes locais africanos dos filhos, não se inibiu de os mencionar relativamente a pessoas da sua intimidade. Há uma excepção. A sua filha Maria é identificada no Diário quando Silva Porto lhe dirige uma carta de negócios em 1885 (Benguella, é o nome que aparece em muitos documentos, induzindo a que esta filha tivesse o nome de Benguella. Contudo, este termo era usado por Silva Porto quando escrevia à sua filha Maria que vivia em Bengela). Em 13 de Fevereiro de 1863, Silva Porto recebe o aviso da morte de mais dois filhos seus (PorTo cf. Manuscrito, Vol. III-A: 107). ${ }^{6}$ Mais tarde, um outro filho, Manuel Francisco Ferreira, foi sepultado no cemitério do Kalundu em Bengela (Idem: 113). ${ }^{7} \mathrm{~A}$ relação de Silva Porto com a grande família sustenta-se na filiação matrilinear da sociedade bantu da África central, em que se enquadram os povos vizinhos Vanyaneka, Tucokwe, Vangangela e Ambundu. Eram potentados ligados por laços económicos e matrimoniais,

6 Quando se encontrava em Bengela Silva Porto recebeu em carta transportada pelo vapor D. Pedro, a notícia do falecimento do filho Francisco da Silva Porto e, posteriormente, de um outro filho, Narciso da Silva Porto. Narciso da Silva Porto, falecido a 22 de Maio de 1862 e Francisco da Silva Porto a 10 de Dezembro do mesmo ano. Nesta ocasião decidiu remover o cadáver do seu finado amigo Manuel Francisco Relvas para junto da campa do seu filho Manuel Francisco Ferreira da Silva Porto.

7 Quando faleciam os filhos, quer em Portugal quer em Angola, ele mandava celebrar missas às quais a família materna se associava. As missas eram celebradas de acordo com as normas cristãs e tradicionais. «Faz hoje um ano que faleceu nosso querido filho António da Silva Porto. E por tão infausto acontecimento era nosso dever mandar dizer missas pelo eterno repouso da sua alma. Não o fizemos e Deus sabe o porquê existem gravados na nossa alma como pai e amigo dos nossos filhos, e por este motivo é que não cumprimos agora, não faltará ocasião em que levaremos à realização...» Passado algum tempo faleceu seu amigo Manuel Francisco Relvas, que tinha o mesmo nome do seu falecido filho. 
tal como é o caso, por exemplo, da sua terceira esposa (Idem, vol. vi: 414-415 [24 a 25 de Junho de 1862]). ${ }^{8}$

Como referimos, os casamentos de Silva Porto tiveram uma implicação directa com as famílias das mulheres. Isso originou relações afins entre sogro e genro, entre os pais, tios e tias das mulheres de Silva Porto e as relações entre irmãs, primas, que são relações por aliança e os sobrinhos, netos, dessas famílias, que se designam em África por relações familiares. Dos filhos que Silva Porto teve com as várias mulheres, no vasto espaço territorial entre a África central e austral, criaram-se vínculos com as respectivas famílias dessas mulheres, conforme este menciona no seu Diário. São essas relações que tornaram possível a integração de Silva Porto nas respectivas comunidades. Quando chegasse a uma comunidade era acolhido tanto pela sua família quanto pela comunidade.

\subsection{As viagens de Silva Porto e comércio a longa dis- tância}

Silva Porto preparou a sua carreira de sertanejo na África central e austral, através de várias viagens que realizou a nível individual e oficial, no quadro conjuntural político da época. Organizou as primeiras viagens entre 1840-1856, em caravanas comerciais com os seus makotas (carregadores experientes e conselheiros) e um vasto conjunto de pessoas que integravam os seus pombeiros e serviçais, a partir do litoral de Bengela, com destino a várias zonas da África central e austral.

8 Silva Porto transcreveu no seu Diário alguns episódios ocorridos com membros da família das suas esposas, em diversas circunstâncias: «[...] hoje faltou-nos um "preto" do Sumbe, e a fidalga, mãe do nosso filhinho Salustiano. Aquele fugiu provavelmente em companhia dos selvagens para sua terra, ou outra, e esta deve de estar em Bengela. A sua falta é originada de a fazermos trabalhar junto as mais depois do dia 17 do corrente, visto que sendo uma pessoa que sempre existia em casa, tinha de obrigação vigiar para que se não dessem os distúrbios que se deram; a fim de lhe pôr cobro ou então participar-nos tal impossibilidade, para tomar-mos as nossas medidas, porém nem uma nem outra coisa, sendo o seu castigo seguir para o trabalho, o que tomou como afronta; o que é coisa certa de mau exemplo para o geral, principalmente não tendo nós nada em nosso favor, e ela tudo a seu, por causa do filho que já dissemos [...]». Mais tarde a mãe de Salustiano aparece e «[...] para não continuarmos a sofrer enviamos-lhe para a fazenda Estrela temporariamente $[\ldots] »$. 
Em 1840, Silva Porto responde ao apelo do então governador, Manuel de Almeida Vasconcelos, sobre a expansão da rede comercial para as terras do interior, com o fim de se evitar a concorrência de estrangeiros. Atingiu o planalto central para aí desenvolver o comércio a longa distância, conforme narrou: « $A$ partir da década de 1820 a livre difusão através do sertão vem a ser um facto consumado» (Alexandre e Dias 1988, vol. 9: 325). O comércio a longa distância estava ligado aos entrepostos do Viyè e de Luanda, numa rede comercial que penetrava no sertão através dos presídios do Kwanza, Malanje, Musende até à feira de Kasanji, ramificando-se transversalmente a partir de Mpungu a Ndongo para o Sul, atingindo o planalto central de Angola e chegando ao Viyè.

Na década de 1840 , a abertura de rotas comerciais para o centro, sul e leste da África central e austral provocou uma expansão comercial bastante significativa nas terras dotadas de novos produtos, tais como o marfim, a cera, a goma copal, a borracha ou a urzela. As caravanas do sertanejo percorreram várias direcções da África central e austral, num espaço de 16 anos. Em 1847 e 1848, Silva Porto já tinha viajado para Barotselândia, e os seus agentes fizeram-no entre 1850-1851. A partir de 1845 fixou-se em Bengela, de onde começou a enviar os seus «comissionários» até ao Alto Zambeze. Percorreu a imensa região que se estende entre Bengela, Alto Zambeze e Kasayi, auxiliando sertanejos, exploradores e missionários europeus que afluíam à região.

A actividade do comércio sertanejo no Viyè começa a ter o seu maior impacto na segunda metade do século xIx. Entre 1845 e 1874 a África central achava-se integrada no comércio internacional pela via do comércio a longa distância. As manufacturas europeias, em troca indirecta de escravos enviados para América, que por sua vez eram produtores de géneros consumíveis pela Europa. Assim, estabelecia-se um circuito da economia atlântica, centrada num único sentido: da Europa para África e América com as manufacturas; da África para a América com comércio de escravos; da América para a Europa com algodão, açúcar e outros produtos comerciais.

A partir das rotas tradicionais existentes nas regiões da África central, Silva Porto incrementou o comércio a longa distância, estendendo toda a sua actividade comercial entre o Viyè e várias 
direcções da África central e austral. ${ }^{9}$ Estabeleceu a rota através das redes comerciais que partiam do Planalto Central no Viyè até ao litoral de Bengela. ${ }^{\mathbf{1 0}}$ Estavam assim estabelecidas duas grandes linhas de penetração do comércio, a saber: uma, a partir de Luanda pela via do corredor do Kwanza, e outra, saída de Bengela, pelo Viyè, Mbalundu, interior de Kakonda, Kilenge e Katumbela.

Silva Porto tomou a liderança das actividades mercantis a partir do Planalto Central. Quando este chegou a Angola, o entreposto do Viyè já estava integrado na rede mercantil de Luanda. O principal objectivo era o comércio a longa distância que continuava baseado na aquisição de produtos africanos para o tráfico transatlântico. $\mathrm{O}$ Decreto de 10 de Dezembro de 1836 «proibia a exportação de escravos a partir das colónias portuguesas». Em África, os escravos continuaram a ser os actores da escravidão que, no entanto, estava longe de ser um mal resultante de um falso princípio de consciência, tal como o afirmou Rosário Pimentel (cf. Pimentel 1998: 198). Percebe-se que os administradores locais não programaram a aplicação do Decreto, nem, muito menos, os instrumentos régios para a repressão das medidas do tráfico.

Entre a costa atlântica e as regiões do interior, a principal mercadoria nas transaç̧ões comerciais de curta e de longa distância era o escravo. Silva Porto descreveu no seu manuscrito: «Logo quem compra escravos há quem venda [...] o escravo é e será sempre uma mercadoria como outra qualquer que levamos ao mercado [...]» (PorTo cf. Manuscrito, Vol. v: 29). Observa-se, assim, que a

9 Atendendo à sua condição de emigrante e comerciante sertanejo a título individual, o contacto com a sociedade portuguesa era difícil para Silva Porto. Tal como se pode inferir da leitura da nossa tese de doutoramento, este emigrante adoptou técnicas e saberes locais da cultura ovimbundu para incrementar as suas actividades comerciais em quase todo o território ovimbundu até à zona Leste e Sudeste da África central e austral. A falta de superioridade técnica, de recursos financeiros e meios, dificultou, muitas vezes, o avanço e aperfeiçoamento desta modalidade comercial, que exigia grandes investimentos e apoios das chefias e populações locais, bem como da integração das normas das culturas encontradas. Não obstante tais factos, não estava inibido o recurso ao uso da força para, num jogo de forças com as chefias políticas locais se definir as «contendas», recurso esse que possibilitou algum sucesso relativamente às transacções da urzela e da borracha.

10 O planalto do Viyè era um centro intermediário que funcionava com uma grande ramificação na África central, para além fronteiras numa extensa rede de comunicações mantidas e prolongadas entre eles. Assinala-se o Viyè como o principal entreposto deste comércio de longa distância que durou dois séculos, com grande incidência em todo o século XIX (cf. SANTOS ed.: 1986). 
vida de Silva Porto no Viyè é desenvolvida na base de uma actividade mercantil, baseda na necessidade de obtenção de produtos africanos, que tinha como principal objectivo comercializá-los nos mercados internos, regionais e internacionais. O período compreendido entre 1841 e 1887 marca a fase de actividade mercantil de Silva Porto a partir do Viyè, com destaque para o período entre 1841 e 1845, porque o tráfico de escravos teve um impacto comercial na actividade mercantil. Silva Porto menciona os escravos domésticos nas seguintes categorias: «moleques» (nleke), «peças», «munanu» e «apanhadeira». Dos trabalhos já realizados acerca deste assunto, estima-se que a média anual de escravos domésticos na residência de Belmonte era de cerca de 150 escravos (SANTOS 1999: 220).

Em 1845, Silva Porto promove viagens a África Central para iniciar o comércio a longa distância entre o litoral e o interior de África central e austral. Em 1852 realizou parte da viagem transafricana de Angola a Moçambique, uma travessia oficial, mas parou em Katongo (Zâmbia), e alguns dos seus pombeiros prosseguiram a viagem. De 1854 a 1869, Silva Porto realizou três viagens a Bengela, para permuta de escravos, marfim, cera, borracha, goma elástica, urzela e algodão. O escravo já era uma mercadoria considerada ilícita, por isso houve uma queda na sua comercialização a nível transatlântico. Observa-se, assim, durante esse lapso de tempo, uma subida do marfim, da cera e depois o auge da borracha e urzela entre 1860 e 1870.

Houve uma interrupção nas viagens entre 1870 a 1879 , por se ter estabelecido em Bengela com a actividade de agricultor. No entanto, retoma as viagens em 1880, período em que se verifica uma progressão das viagens transafricanas a nível pessoal, ao território Kuba em 1880; ao Lwi (Barotse) em 1883; a Bengela em 1884; a Kalundu em 1885 e novamente a Bengela em 1888. No cômputo mais geral o período que, na óptica da liderança de Silva Porto, permite uma correcta avaliação das actividades mercantis, é entre 1841 e 200 1887, com o fim do tráfico de escravos.

Em 1845, Silva Porto organiza a primeira caravana - kitoko, nome dado às caravanas - para se dirigir a Bengela. Em seguida ao Barotse com os seus pombeiros ao Lwi, no Lukulu, chefiada por Joaquim Mariano Kahopo. ${ }^{11}$ Foi uma viagem de várias frentes. O chefe Lutembu exigiu tributo pesado de passagem, enquanto o osoma

\footnotetext{
${ }^{11}$ Pombeiros eram os carregadores da rota de feiras regionais designada Mpumbu.
} 
Kabita «abriu mão» da passagem. No território de Hikului, o chefe dos Mulozi, soberano Riumbu, travava uma guerra com o seu vizinho Makokolo. Em 1847 realiza outra viagem ao Lwi, Barotse e Zâmbia (РоRTо op. cit., vol. I: 71-79).

A linha de contacto comercial de Silva Porto era estabelecida entre as vastas zonas regionais do interior e do litoral atlântico, constatando-se uma grande influência colonialista, que recaía no comércio sertanejo a longa distância. Maria Emília Madeira Santos, que trabalhou sobre essa matéria, reafirma que as características e a extensão dessas ligações eram essenciais à vida das áreas portuguesas da África austral (SANTOS 1999). Verifica-se que vários emigrantes portugueses dessa época criaram estruturas comerciais baseadas nas antigas rotas tradicionais, a partir do centro de Angola-Viyè, para várias direcções de África central e posteriormente da África Austral, região onde expandiram negócios nos territórios entre o vale do Zambeze e a costa oriental. O Viyè constituiu assim uma placa giratória em torno das redes comerciais que se foram alargando na zona transfronteiriça. A sua localização, no Planalto Central de Angola, facultou um fácil acesso a Luanda e Bengela e constituiu uma excelente base para chegar aos mercados da África central, para onde se destinavam as cargas europeias, e para a obtenção dos produtos africanos, como escravos, marfim, urzela e algodão.

A Capitania-mor no Viyè atraiu muitos viajantes, conforme reportou Silva Porto: ${ }^{12}$ "vagos sem lei [...] fugidos das prisões e vêm cumprir penas, estes comprometem os que aqui pretendem em bom nome fazer os seus negócios, deviam entrar na fortaleza [...]» (PorTo op. cit., vol. III). Silva Porto não deixava dúvidas quanto à sua inquietação acerca da presença no Viyè de emigrantes de diferentes origens e classes sociais. Considerava que apenas ambicionavam fazer fortuna e já rondavam um número considerável. A rede de expansão comercial começou no Centro, com a realização de várias viagens ao Alto-Kasayi em $1794 .{ }^{13}$ Cerca de duzentos sertanejos habitavam no Viyè, e toda a sua acção comercial se propagava até ao Alto-Cikapa (hoje Lunda-Sul), Kazombo, Lovale (na actual província do Moxico). Em 1852, a frente de uma extensa caravana, Silva

\footnotetext{
12 Durante o mandato de Francisco da Conceição Matos entre 1792 e 1820 foram estabelecidas condições capazes de atrair um grande número de sertanejos àquele Estado.

13 Trata-se da viagem celebrada pelo sertanejo Alexandre da Silva Mota (cf. MotA, in Arquivos de Angola, vol I, n. ${ }^{\circ}$ 4, Novembro 1935, doc. x).
} 
Porto viajou para as terras da Lunda. Transpôs os territórios a norte do Kwanza e Kwangu, e estabeleceu contactos comerciais com os Aruund (os Alunda dos portugueses), os Tucokwe, os Luluwa, entre outros povos aparentados.

\subsection{Silva Porto e a língua umbundu}

Silva Porto assumiu a necessidade de um profundo conhecimento da língua umbundu para se integrar no meio viyeno. A língua é o veículo da cultura e de todo o património que a acompanha. Assim, começou por assimilar a língua umbundu ao manifestar a necessidade de se comunicar com o meio utilizando-a como língua de contacto. Inicialmente utilizou os termos umbundu ao instalar-se nesse meio social, tal como o próprio reporta. Transcreveu um glossário umbundu no seu Diário, usando sempre o etnónimo e adjectivo umbundu para se exprimir na sua vida de relações. Partindo da interpretação dos termos que aplica em língua local apercebemo-nos que Silva Porto, inconscientemente, utilizava a língua local na sua redacção do Diário para se referir à sua condição social. Até que ponto a língua umbundu foi um elemento de integração para Silva Porto?

Apresentamos alguns exemplos do alfabeto em língua umbundu, constantes no Diário de António Francisco Ferreira da Silva Porto:

«Descrição dos nomes de todos os répteis mais perigosos daqui [...] dos animais ferozes, das terras» (léxico em umbundu, cokwe e ciluba).

«Vocabulos. O idioma umbundo falo de vocabulos proprios a significar o verdadeiro sentido das palavras a que devem sêr applicados Có-féra. Vocabulo indicativo do futuro, e quer dizer a estação do vento e do frio». Tradução nossa para língua umbundu - Kofera. Chimbo, crime (ciymbo)» (РоRTо Manuscrito, vol. XI, 19 Abril 1885-86-87-88).

Paleografia no Diário de Silva Porto:

«Que o capital se junte e as companhias se organizem. Há vasto campo para commercio; para o homem de sciencia immortalizar o seu nome; para o historiador que se encarregue de escrever a história do paiz; virgem de tudo quanto é proveitoso e util. Semear, semear, para mais tarde colhê» (Idem, vol. XI, 13 Abril 1884-1885-1886-1887).

O sertanejo também se interessou por recolher os termos de classificação da fauna e flora para melhor compreender o ecossistema 
da região do planalto central: «vamos dar conta em classificação scientifica, como nos mesmos volumes se encontra, a dos animais que temos descripto em tempo no idioma umbundo e são pela sua ordem: Folhas 21 do $3 .^{\circ}$ volume da ilustração luso brasileira, Relva. Quicema. 3 - Leão. Elefante - Jamba, mas os indígenas empregam os vocábulos Jamba-Guébe, para designar gémeos» (Porto Manuscrito, vol. vII, 26 a 27 Agosto 1862).

Com a aprendizagem da língua umbundu, Silva Porto conseguiu manter as relações com a família, com a corte e no comércio. Por essa via este passou a falar fluentemente a língua umbundu, descrevendo um glossário aturado em termos umbundu e ngangela: os hidrónimos, Rios Keve, Cutato dos Mongóias, Kukema, Kavaku; antropónimos, Lumbu, Mbandwa, Ntembo, Inakulu, Kafoko, Kandimba; etnónimos, raça Lobale, Quimbundo, Ganguela, Bunda; Orónimos, montanha da Catiaballa, Candundu, morro da Catumbela. Em suma, esse léxico que Silva Porto elaborou permitiu-lhe um conhecimento aprofundado do meio ambiente em que se inseriu, pelo domínio da língua. Por sua vez, os Ovimbundu assimilaram a língua portuguesa; aprenderam a falar e a escrever a língua portuguesa com Silva Porto, durante um processo de alfabetização, ensinando as suas mulheres, filhos, e todos os seus educandos da sua responsabilidade na ombala. No final da época de 1870, Silva Porto fundou uma escola em Belmonte para a aprendizagem do português com vista a resolver problemas comerciais.

Figura 4. Escola de Belmonte na ombala Porto no Viyè. À esquerda Silva Porto e no centro o padre Joaquim Fidalgo com os alunos

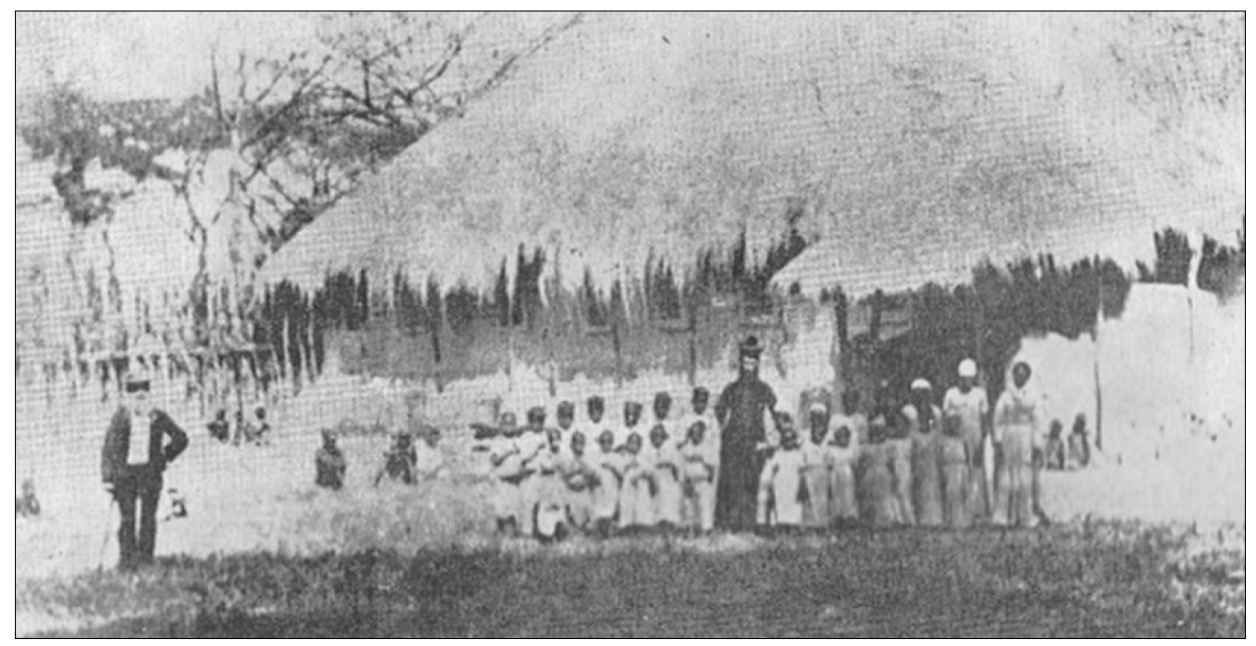

Fonte: Silva Porto, in Diário, vol. XIII 


\subsection{As viagens internas de Silva Porto}

O circuito de viagens internas do sertanejo delimitavam-se ao espaço que integravam a região da África central, que hoje compreende geograficamente o Leste de Angola. Durante estas viagens internas, a convivência entre os membros e os condutores das caravanas (kisongo) era aprofundada com conjugação das normas (kitoko) ovimbundu e europeias. Nessas viagens, os mercados, as feiras, determinadas matérias de culto e de tratamento tradicional, de empossamento e de guerras, contribuíram para o seu conhecimento sobre o meio, sobre as entidades, os códigos de viagens, as regras de relacionamento com as mulheres, de angariamento dos carregadores, da troca dos produtos e das múltiplas formas para solucionar questões. As viagens incrementadas por Silva Porto possibilitaram-lhe conhecer a estrutura de funcionamento e formas de integração pela sua convivência nesse meio. Indicaremos algumas dessas deslocações, que ajudaram a tornar possível a sua integração no meio ovimbundu.

Em início de 1862, Silva Porto realizou duas viagens do Kwitu a Bengela. Antes da sua partida, a caravana foi interpelada por alguns hóspedes com vista ao cumprimento do ritual da nomeação do chefe (Idem, vol. vII, 1862: 301-302). Estes foram servidos de abundante bebida de kapata, um boi, uma ancoreta de aguardente, «presente da maior consideração que por aqui se pode oferecer a quem quer que seja de elevada hierarchia». ${ }^{\mathbf{4}}$ As viagens permitiam a Silva Porto, avaliar o nível dos seus carregadores, conhecer as capacidades de cada um deles e interagir no meio comercial. Antes e depois das viagens havia uma partilha de saudações, para cumprir as regras da viagem. O emissário do soberano do Viyè, vinha de Ekovongo; dirigia-se ao sertanejo entregava-lhe alguns produtos e

14 Silva Porto descreve a biografia do seu empregado: Urbano J. Reis era bastante criança quando em companhia da mãe, irmãos e irmãs, veio para nosso poder; prático em noções das primeiras letras e contabilidade, junto aos irmãos entregou-se ao comércio do interior onde seguia com fazendas nossas, prestando contas regulares e usufruindo interesses de menor valor; conseguindo com tais meios organizar uma povoação respeitável com serventes de ambos os sexos, que resgatava adicionando aos serviçais obtidos nas viagens com a mudança da localidade do irmão Gonçalves dos Reis. 
recebia dele, outros. ${ }^{15}$ Levava como missão do soberano solicitar a sua participação numa sessão de culto (PoRTo, Diário [Manuscrito], vol. viI: 310).

Em Agosto de 1862, durante a segunda viagem a Bengela, travava-se uma guerra contra os Imbangala de Kasanji (Idem, vol. vII, 7 Agosto 1862). Silva Porto foi informado pelo Osoma Ekovongo do Mbalundu, que lhe oferecera um serviçal de presente, da morte do Osoma Kambala e a elevação de outro vigente no poder. No mesmo momento, encontravam-se emissários de Mpungu a Ndongo a anunciar que iriam convocar a guerra contra o Imbangala «jaga» de Kasanji. Todos os sertanejos se envolveram nesta guerra. Silva Porto fez parte da mesma, introduzindo os seus homens em Mpungu a Ndongo para o combate.

Da mesma viagem a Bengela, apareceram no Kwitu, partindo do kilombo da caravana do Mikeselumbwe, ungidos de memba (ou mpemba) que significava o sucesso da viagem comercial (Idem, vol. VII, 1 a 4 Setembro 1862). ${ }^{16}$ De forma geral, a cultura umbundu, tanto quanto nas culturas bantu, essas cores são cores dos rituais. O vermelho significa «maldição», «insucesso», «guerra», ao contrário da cor branca, a memba, que significa «paz», «harmonia», «sucesso». A prática desses rituais, durante essa viagem, prova que Silva Porto foi aprendendo os seus códigos, as suas regras, factos que lhe facilitaram a adaptação ao cumprimento dos itinerários comerciais.

Em 14 de Maio de 1862 partiu uma caravana comercial de Silva Porto para as terras do Sambo, em negócio de fazendas (Idem, vol. VII, 21 Novembro 1862: 378). Mas a caravana foi atacada por salteadores que mataram o seu chefe, o makota Paulo, e assassinaram mais três membros. Esta notícia da morte do makota Paulo, chefe da caravana do Sambo, abalou emocionalmente o sertanejo porque com ele havia trabalhado durante 20 anos sem nunca lhe ter sido infiel, a ponto de ter rejeitado propostas dos seus parentes do Lovale, de onde era originário, e para onde já tinha feito duas ou três viagens com fazendas de negócios na permuta de cera e marfim.

15 O soberano informou-o da sua ausência na solução de um problema, dado que estava ocupado na resolução de doenças, «de kimbandas, para completar curativos de seguir para a guerra, para depois comunicarem ao sertanejo a fim de assistir o culto de adivinhação».

16 Os pombeiros transportaram cordas de entrecasca de árvore para fazer a ponte, a caiadura do arvoredo frutífero, por causa do piolho e da formiga que se chama longinge. 
Deste modo, através de experiências práticas, Silva Porto aprendeu a gerir os problemas dos assaltos de caravanas, criando diálogos e estabelecendo tácticas de avanço.

A viagem prosseguiu e passaram o rio Kukema, pela libata grande do Katemo enviando a kibanda ao Osoma. Continuaram e fizeram kilombo na Nyalã Mbulu Mvulu. O Osoma deu-lhes de presente um carneiro e kindas de milho, que o sertanejo retribuiu. Encetaram uma longa conversa sobre as nascentes dos rios: Kayangaralua, Kune, Kunhinga, Kunji, Kukema, Kwitu, Katemo, informando o Osoma que os seus antepassados habitavam na margem esquerda do rio Katemo, e ele ali habitava para não se opôr à vontade dos seus antepassados. Despediram-se cordialmente e uma vez já na outra margem do Kukema, o sertanejo foi surpreendido com o ritual: Ambangéro! Anganna!..., significando: «O encontro! Senhor!...» Com grande coro musical proveniente da libata grande (palácio real). A 19 de Dezembro, passaram pelos matos de Kitekumuna, o rio Bar e o prado Longimbo, entrando nos matos de Bielle (Vihele), passaram pela libata grande, enviaram a kibanda na margem direita do Kutatu dos Mongóias e fizeram quilombo (Idem, vol. vII, 18 a 19 Outubro 1862). Essa via intransponível para as viagens de Silva Porto ajudaram-no a conhecer uma parte dessa vasta região delimitada entre Viyè e Bengela, a compreender a tradição dessa região e serviram de elementos de uma parte etnográfica para compôr o seu Diário.

\subsection{Silva Porto e a religião}

A base de formação de Silva Porto assentava na religião católica. No entanto, conviveu com elementos da religião tradicional interpretando-os a partir da concepção religiosa do universo católico. É que Silva Porto não se adaptou aos elementos da religião local, mas, por conveniência e respeito, acompanhou e participou em alguns rituais locais. Transcreveu esses elementos no seu Diário, factos que justificam o aspecto variável da religião enquadrar-se no processo de assimilação. Por exemplo, uma das viagens de negócios ao território de Umbukusu, dirigida pelo seu dikota pequeno, foi bem sucedida e Silva Porto usou as orações da sua religião cristã para proteger o seu makota: «Deus o proteja» (Idem, vol. vI, 11 Junho 1867: 3). Enquanto isso, o makota agradecia ao Suku (Deus). Na véspera da partida para as «Ngangelas», Silva Porto decidiu comemorar com capricho 
a data do seu patrono, e isso com vista a «abençoar» os lucros nos negócios e a saúde e bem-estar da caravana, dando panos à sua gente e aos escravos de ambos os sexos. Silva Porto conciliava a benção do seu patrono com a kibanda, tributo ao osoma, no lucenji (recinto de audiências, fora da residência); pela morte por afogamento do escravo no rio Kuvangu, escreve: "o pombeiro era um "preto" da libata grande que esteve no Umbukusu e que devia seguir para a residência do mesmo em virtude dos "feitiços" (Idem, vol. vI, Junho 1869: 32).

A cerimónia decorreu perante sargentos, makotas. Silva Porto dizia que a sua participação era só para entregar a kibanda, o tributo da morte do escravo. Neste contexto, Silva Porto tolerou a religião tradicional ao assistir a esta cerimónia do Ongombo, que consistia na adivinhação dos «feitiços». A praga de salalé prende-se com outro culto, que ele designava por insecto destruidor, «um imitador da arquitectura góthica, artista destruidor daquilo que é belo, quando penetrou em forma de zig-zag na sua barraca do kilombo, encostado a um fardo de fazendas, 4 peças, uma capa», que as destruiu ficando estas completamente inutilizadas. A aparição deste insecto em pequenos filões à porta de casa é um sinal de mau presságio, um azar, algo grave prestes a acontecer, anúncio de uma doença ou morte. Quando danificavam objectos domésticos, comerciais e outros em casa, realizava-se o culto e ritual de ondjingongolo. Nesse âmbito, Silva Porto assistiu ao rito religioso para afastar os maus espíritos (olondele) e apelar aos bons (olosande) dirigido por um especialista, por vezes pelos próprios autóctones que, segundo o sertanejo, sabem fazê-lo em casos simples de emergência. Silva Porto considerou este culto de «feitiçaria», «adivinhação» feita pelos «selvagens», que usam o mal por meio de adivinhações prescritas pelo adivinho. À semelhança de todos os outros também esteve presente. Na África central as térmitas estão relacionadas com o sagrado. Têm também um significado místico. Nelas habitam os répteis rastejantes (cobras e jibóias). Para associar-se à prevenção e expulsão deste mal, Silva Porto criou a técnica da areia colocada na abertura das portas.

Foi a partir de 1860 (Idem, vol. XI, 1884 a 1887), que a ombala de Belmonte foi atacada por esta praga, «salalé-térmite» (AzEvEDo 1984). ${ }^{17}$ Apesar de considerar os sacerdotes como «adivinhos» não

17 O salalé-térmite é um insecto pertencente ao domínio da entomologia, a formiga-branca. 
conseguiu estabelecer a diferença entre este e o balaio do ongombo, mas interiorizou a cosmogonia umbundu no seu modelo religioso ao aceitar "Kalunga a "excelência", em toda a vida e depois de mortos». Acrescenta que os Ovimbundu vão depreciar sobre as suas sepulturas, ou na casa que serve de depósito das suas caveiras, por serem reputados entre os sobrenaturais; assim como o Kuku, que tem várias significações segundo a sua aplicação. Se Silva Porto se mantivesse unicamente aliado à sua concepção religiosa, não teria a preocupação de transcrever e interpretar a concepção religiosa ovimbundu. Isto significa que absorveu valores religiosos ovimbundu, como um veículo cultural. Através dessa concepção, o sertanejo garantiu a união e a harmonia para a coesão com os vários subgrupos ovimbundu e a mesma forma de se comunicarem com o Ser Supremo, intercedidos pelos espíritos antepassados, seus intermediários. Silva Porto não se adaptou à religião tradicional africana, mas tolerou-a tendo em conta as necessidades da sua sobrevivência no meio ovimbundu. Resistiu e tolerou, mas não conseguiu furtar-se à sua concepção religiosa católica, que também a introduziu entre os ovimbundu, ao criar a missão católica de Belmonte.

\subsection{Silva Porto e a alimentação}

A alimentação é um factor de aproximação e união entre os elementos de diferentes comunidades. No caso de Silva Porto, a transição dos seus hábitos alimentares portugueses para os hábitos alimentares ovimbundu, exerceu uma grande influência na sua vida no Viyè, sobretudo durante o seu processo de integração na sociedade ovimbundu. O sertanejo consumiu alimentos que eram produzidos no meio em que estava inserido. $\mathrm{O}$ facto de se ter casado com mulheres ovimbundu, facilitou o consumo de alimentos locais. A base alimentar umbundu era constituída por cereais: milho, masangu, mandubi; por legumes; carne ovina, suína, caprina e ovícula; leite e ovos. Silva Porto descreveu o seguinte: «Fomos assistir hoje ao nosso trabalho agrícola, orientando os indígenas a preparar $o$ terreno para a sementeira do grão, significando animação geral no tracto da vida» (PoRTo Diário [Manuscrito], vol. viI, 6 Agosto 1862). Esta cultura do grão e trigo era diversificada pelo sertanejo em vários pontos de África central onde se encontravam os seus estabelecimentos, nas margens do Kwitu e Kangondo. 
Em 5 de Setembro de 1862, Silva Porto começou a armazenar em celeiros o trigo, como referiu no seu Diário: «vamos apresentar ao nosso leitor, o resultado da colheita realizada em diversas ocasiões no correr deste ano: tenho que acrescentar que a medida daqui regulada por alqueire e meio do litoral, ou dois alqueires pouco mais ou menos de Portugal». A actividade da pastorícia também foi praticada por Silva Porto; a carne bovina, suína e caprina fazia parte da sua dieta; contudo quando aqui chegou os Ovimbundu já tinham desenvolvido a cultura do gado.

\section{Quadro 1. Dieta alimentar de Silva Porto}

\begin{tabular}{l|l}
\hline $\begin{array}{l}\text { Produtos que Silva Porto encontrou } \\
\text { nas culturas africanas }\end{array}$ & $\begin{array}{l}\text { Produtos introduzidos } \\
\text { por Silva Porto }\end{array}$ \\
\hline Milho & Feijão \\
\hline Masangu & Ervilha doce \\
\hline Batata-doce & Trigo \\
\hline Soja & Grão-de-bico \\
\hline Abóbora, cogumelos & $\begin{array}{l}\text { Legumes: espinafre, } \\
\text { couve-galega, pimento, cenoura, } \\
\text { limoeiro; frutas: videira, } \\
\text { romãzeira, laranjeira. }\end{array}$ \\
\hline
\end{tabular}

Os produtos cultivados nas lavras de Silva Porto, alguns de origem europeia, eram encomendados aos seus credores, que enviavam uma pequena gama deles como chás e sementes (Idem, 5 a 6 Setembro 1862). Possuía plantações de pomares como limoeiros, laranjeiras, romãzeiras e videiras (Idem, vol. XII, 7 Setembro 1862). $\mathrm{O}$ destino que Silva Porto dava à produção dessas frutas europeias era a sua dieta alimentar da ombala e dos seus vizinhos. Muitos alimentos passaram a fazer parte da alimentação dos Ovimbundu a partir dessa época. A lavra fazia parte da sua cultura de subsistência e, fundamentalmente, por ser um hábito da sua origem familiar. Ele próprio refere a sua estrutura: «[...] a missão do homem sobre a terra é trabalhar sempre» (Idem, 15 de Outubro de 1862).

Quando viajava do Kwitu para Bengela, em 1862, o sertanejo recolheu na flora da região ovimbundu espécies vegetais para introduzir na sua dieta: diversas espécies de cogumelos próximo do rio Kutatu e Uembe, onde todo o caminho estava alastrado de cogumelos, ou «owa como denominam no idioma umbundu, tão útil vegetal 
[...] útil pela circunstância de servir para toda população». Silva Porto aprendeu a técnica da colecta do owa. As espécies que recolheu, denda, couceque, uasasera, colele, onguri, ca-condomboro, ulundo, etc., entre espécies venenosas como himboto, kalumbo $e$ ubetu. No total somavam trinta e três (33) espécies (Idem, vol. vII, 20 Dezembro 1862: 384-385). A técnica de preparação da terra para a sementeira dos produtos era feita em conjunto com os makota (Idem, vol. vi, n. ${ }^{\circ}$ 1241: 374). Era habitual usar a farinha de peixe seco na falta de feijão e milho, «para aprontar a nossa lavra» (Idem, vol. vi, n. ${ }^{\circ}$ 1241: 303).

A alimentação como variável cultural induziu a uma alimentação mista no processo de transição da cultura alimentar europeia para a ovimbundu. Adaptou-se assim à ingestão diária de alimentos da gastronomia ovimbundu. Muitos Ovimbundu também se apropriaram de alimentos europeus através da relação partilhada com o sertanejo.

\section{O fenómeno da transculturação em Silva Porto}

Constatamos que as distintas variáveis apontadas determinaram a efectivação do fenómeno da transculturação em Silva Porto, baseada concretamente no encontro com a cultura ovimbundu, onde absorveu elementos culturais. É uma prova de assimilação cultural ovimbundu. Terá sido transversal? A população ovimbundu recebeu elementos culturais portugueses através da integração de Silva Porto?

Os níveis de evolução das variáveis de transculturação sugerem o seguinte: $O$ casamento foi o nível mais elevado da transculturação onde Silva Porto assimilou os elementos culturais. As viagens que contribuíram para o conhecimento do universo ovimbundu que Silva Porto integrou. A língua foi o factor determinante na sua integração para melhor conhecer e dominar o espaço ovimbundu. Silva Porto não se adaptou à religião africana, resistiu mas tolerou-a introduzindo elementos da religião cristã na sociedade ovimbundu. A alimentação foi um factor de integração ao consumir a dieta alimentar africana.

A deslocação de Silva Porto entre diferentes cartografias da África central, em pleno processo transcultural, configura-se através da história social do século XIX. Ao manter-se em contacto com uma diversidade cultural no espaço etnolinguístico ovimbundu, esse 
facto levou-nos a questionar onde e como esses espaços foram absorvidos por elementos culturais e como terão ocorrido esses movimentos de transculturação. A esse propósito, Mary Louise Pratt é clara e vigorosa ao evidenciar que essa deslocação ocorreu durante um processo prolongado dos europeus em África, num momento em que lutavam para superar obstáculos tendentes a possibilitar o enraizamento de interesses comerciais e políticos (PRATT 2005: 282). A necessidade de atingir um estatuto comercial elevado, perspectivado no vasto espaço da África central e no choque com a cultura ovimbundu, terá ocasionado um impacto social na vida de Silva Porto, exaltado, sobretudo, nas alianças matrimoniais celebradas pelo sertanejo. É que o casamento de Silva Porto surgiu numa circunstância oposta à cultura portuguesa por uma maior acepção da cultura ovimbundu, onde se constata um nível de assimilação muito elevado, constituindo esta a maior variável do iceberg da transculturação. Sendo a instituição do casamento o índice mais elevado na transculturação, ela impulsionou a geração de uma família «lusodescendente» que, estrategicamente, incorporou um processo transcultural.

Quando os seus filhos atingiam a idade escolar eram enviados para Portugal. Analisada a correspondência com Amélia, a sua filha mais protegida, de 1870 a 1889, não restam dúvidas quanto ao objectivo desta querer regressar a Angola logo após a sua formação. Considerando que nesse período liberal o negro era encarado como selvagem, assim sendo, de que forma Silva Porto conseguiu manter uma relação com Portugal? Ter-se-á a filha deparado com situações discriminatórias? De censura? Como terá Amélia vivido em Portugal numa época em que a distinção da raça era um tabu, cuja situação perdurou até ao século xx, apesar da existência de negros em Portugal remontar ao século xv, provenientes de África nos primórdios do tráfico Atlântico, através de alianças e dispositivos acordados entre D. João II de Portugal e D. João II (Nzinga a Nkuvu) do Reino do Kongo. Os filhos de Silva Porto não teriam sido alvo destas representações sociais e linguísticas? ${ }^{\mathbf{8}}$

18 O período de 1887 a 1890 foi de intensa correspondência entre Silva Porto e a sua família e amigos em Portugal e em Bengela, particularmente sobre a situação da sua filha Amélia da Silva Porto que ela descreve numa carta datada de 23 de Dezembro de 1888 (cf. Livro de Cartas e Copiador de Cartas do Sertanejo Silva Porto, Copiador 1879-1889, cartas 1888-1890, s.G.L., p. 67). 
Em 1887-1888, Silva Porto responde a sua filha, acerca da sua insatisfação em continuar a residir no Porto em casa da sua tia dizendo: «infelizmente não mereço». Teria Amélia sido alvo de algum discurso de exclusão social? Ou carregava consigo o sentimento de auto exclusão? É uma questão susceptível de análise psico-social, na medida em que Amélia é o resultado de uma procriação transculturalizante, num meio escravocrata. Quando foi enviada para Portugal era uma criança de seis anos que tinha convivido num meio escravocrata. Amélia teve a mesma integração social, na mestiçagem de culturas (Todorov 1982). A exploração sexual das escravas foi também uma prática secular. Os comerciantes sertanejos no interior da África central usaram as mulheres escravas, geraram famílias que depois integravam também nas suas redes comerciais de tráfico. Muitos chefes africanos contraíam alianças com essa classe feminina «escrava luso-descendente». Instalou-se um circuito da gestação da escravatura em linha horizontal integrada no sistema de parentesco da escravatura interna e moderna. Silva Porto sempre referiu que «o escravo muda apenas de dono e não de condição» (PoRTo, Diário [Manuscrito], vol. XIII, 1889-1890: 7).

O controlo das relações sociais era efectuado pelas autoridades locais. Contudo, Silva Porto registou, na sua correspondência, uma preocupação quanto ao aspecto discriminatório em relação aos filhos. Usando o termo empregue pelo autor acima citado por essas «práticas de comunicação», «os selvagens» foram transversais nos espaços culturais de Silva Porto aplicados aos pombeiros, carregadores, aos seus escravos, às suas mulheres serviçais e até aos filhos conforme transcreve no seu Diário: «[...] em Belmonte tenho uma filha e duas protegidas, estas no cabo de 16 anos a educar em Bengela não diferem dos selvagens» (Idem, vol. XIII, 11 Dezembro 1898: 23). A família de Silva Porto foi construída neste sistema, nas suas representações sociais, resultado inseparável de um conflito cultural recíproco tendo em conta a vontade do colonizador (LÉvi-STRAuss 1983: 75).

O segundo domínio da integração cultural de Silva Porto é o desenvolvimento de viagens que contribuíram para o conhecimento do universo que Silva Porto criou. Mereceram um conhecimento do «outro» a que Rosseau, citado por Tzvetan Todorov, afirmava: «É preciso conhecer as diferenças entre os homens, não porque o particular seja precioso em si mesmo, mas para adquirir luzes sobre o homem em geral» (Todorov 1982: 37). A forma de compreender o «outro», permitia-lhe atingir o conhecimento de uma cultura 
diferente da sua, que ia absorvendo à medida que percorria esses territórios da África central e austral, com cargas de manufacturas europeias transportadas pelos escravos e carregadores, organizadas e lideradas pelos seus makotas de confiança (pombeiros, chefes das caravanas, com longa experiência de viagens comerciais).

Considerou-se um quadro evolutivo das estatísticas das cargas transportadas por este grupo de serviçais permanentes durante as viagens e a maneira como ele as geria no comércio a longa distância: Em 1879, «em Ximwamwka, transportada pelos pombeiros, 1 carga Kasoma e os carregadores Havulwua, com 17 maços de kasungo branco, "pago". Ainda na mesma aldeia de Havulwua foram transportados cargas com 7 maços cada um de kasungu branco pelos carregadores 5 banzos Kalupétika. Em KwaSoma, foram transportadas as cargas pelos pombeiros Mwaatchalo, com 6 banzos e 7 maços, de kasungo branco, no Mbongo, o pombeiro Nangombe com 7 mbanzos de 7 maços, os Mbalundu com maços de arroz» (Notas das cargas para o Viyè). A este propósito, Todorov conceptualiza do seguinte modo «viagem» e «narrativa»: «geralmente, a viagem coincide com a vida, o que permite questionar se esta seria uma passagem do nascimento para a morte» (Idem: 93-105); com o deslocamento no espaço como signo primordial, parece-nos mais fácil a mudança, porque vida é mudança, estando por isso os dois termos implicitamente interligados. A viagem de Silva Porto no espaço da África central implicou uma enorme mudança cultural explícita na sua narrativa de vida; foi a passagem de um tempo do seu deslocamento, numa relação de alteridade que existiu entre Silva Porto e os seus subordinados convertidos no espaço ovimbundu. Esse processo qualificou-o no segundo nível do iceberg da transculturação.

O factor linguístico em Silva Porto foi o terceiro elemento de integração cultural. A posição de seus escravos intérpretes ou informantes, a circulação das mulheres escravas, nas suas actividades cíclicas nos três territórios principais Viyè, Bengela e Katongo, permitiram que a variável linguística favorecesse a condição de difusora da língua umbundu. Representa no icerberg da transculturação de Silva Porto o terceiro nível. Para se inserir numa vida activa comercial e agrícola, a evolução semântica da linguagem em Silva Porto é assegurada na transcrição do seu Diário. Parece-nos claro o esforço que desempenhou em redigir tal como se falava ou percebia, inclusive até o seu próprio nome em umbundu, que assumiu Mpoloto (corruptela de Porto). 
O seu discurso narrativo é transcultural empregando termos em língua portuguesa de alteridade e hibridismo: sitio Lowata raça Luba - anthropophagos - dominio de Kisongo Makinhama (PoRTo, Diário [Manuscrito], vol. XI, 1864-1887). Torna-se cada vez mais visível ao manifestar a preocupação de compilar o glossário com novos exemplos a medida que ia percorrendo o Leste e Sudeste de África Central: «Dia do sitio de Kylolo, de Mwtue Mukulu, no deserto limite de Kalundu,margem do Lubylachy, raça kanhoka, Mwene Va hemba o chefe da raça deste nome antropofago, Mwene Mbangole, Bangecy, Mwatamjyla, Mwene Ngongo, Cynynham» (Idem). Esta descrição da hierarquia do Estado Moyo (Luba), Lunda e Cokwe no Katanga, locais de entrelaçamento cultural, levaram Silva Porto a receber e a dar muitos elementos culturais que lhe permitiram ascender a um nível de assimilação linguística muito acentuado no iceberg da transculturação.

O elemento religioso em Silva Porto foi muito questionado durante o processo de transculturação, por ser considerado parcialmente interiorizado, mas não foi integrado na sua concepção religiosa. O seu universo cósmico patente no mundo cristão fê-lo criar uma igreja e assumir, parcialmente, o papel de pároco na sua libata de Belmonte. Mas conseguirá furtar-se a alguns elementos da cultura religiosa predominantemente ovimbundu, assente nos padrões de Kalunga o Ser supremo, traduzido pela imensidão a que Silva Porto estava envolvido indirectamente? Percebe-se que não estava desprovido da ingerência desses elementos culturais, expressos no Kuku (ancião, representando um antepassado) e em Njambi (Deus) e Mwele. Os objectos de culto, a veneração ao culto dos antepassados, a representatividade cósmica Bantu, passaram a ter um significado ambivalente com a transposição dos elementos cristãos introduzidos por Silva Porto. Os santos, evocados «minha santissima mãe de Cristo redentor», transpostos para o mundo Bantu e em sentido inverso, designou-os de amuleto dos «feitiços» num sentido de rejeição a religião tradicional. Adaptou-se e tolerou-a mas resistiu até um limite. A religião tradicional ovimbundu, entre os lugares de culto e entre as vivências do quotidiano, ocupou o quarto nível em Silva Porto, no iceberg da transculturação.

O factor alimentação é uma das variáveis que levou ao processo de uma transculturação em Silva Porto, depois de ter introduzido vários produtos europeus quer para o comércio, quer para a alimentação da classe luso-descendente. Durante esse processo absorveu 
também os produtos da sociedade ovimbundu, quer os da colecta, da caça dos animais domesticados, num entrelaçamento cultural. As feiras comerciais detinham um capital económico fluído de produtos principais da esfera de influência ovimbundu, nomeadamente escravos, marfim, cera e borracha, produtos que ocupavam o lugar cimeiro, tal como tão bem afirmou Claude Meillassoux: «[...] os escravos diariamente, nascendo escravos ou não, são eles que alimentam a sua própria produção do seu espaço, são engajados na reprodução, nas colheitas» (MeILLASsoux 1986: 127). Existe uma relação entre o escravo e os alimentos por ele produzidos. Este aspecto reflecte a diferenciação entre o escravo produtor de alimentos e o proprietário seu consumidor interno e comerciante externo.

Nos mercados mais longínquos de África central, Silva Porto movimentou grande número de alimentos. A partir do Viyè, fez circular os alimentos através das caravanas comerciais. Lê-se no seu Diário: "carregador Sakachamba com 1 caixa de conhac, carregador Yoma com 1 caixa de açúcar e 4 caixas com passas». Silva Porto destacou os «Pombeiros Kasoma, Cyviwa e Kaley com comércio nos sítios de Yna Soma, de Kacykwma, Losando e Lobando, que, por sua vez, angariaram os carregadores Manuel, Kisapa, Kakiama, Kiñongo, Kayque, Meynda, Mwene Kyalo, Kangombe, Kangole, Kawnguruka, Lwkamba, Kicinge, que transportaram cargas de figos, cominhos, colorau e ancoretas de aguardente». Outras cargas como «sal, presuntos, salame, queijos flamengos, azeite doce, cebola, conservas de sardinha, marmelada, tomate, talheres, azeitonas, da responsabilidade do pombeiro Soma Kwenji, nas localidades de Angwla, Cykopa, Kykwma, Kambendjy, transportadas pelos carregadores Kanjunju, Mwenangambo, Ceyala, Kayombe, Nhyme, Wambo e Kosama» Introduziu, igualmente, o «almude» como medida de venda no sertão (PorTo, Diário [Manuscrito], vol. II: 1-3, 175, 243). A introdução dos alimentos europeus foi maior, mas eram destinados ao comércio, para uma classe europeia e chefias africanas. A classe baixa, a escravocrata, não consumia, mas conhecia-os porque eram os promotores da circulação alimentar, o que teve implicações sociais. A recepção dos alimentos ovimbundu justifica que a alimentação tenha sido um factor de integração cultural ovimbundu em Silva Porto, como o bieylo (cereal), ginguba, masangu, milho, o infundji (alimento confeccionado com farinha de milho, alimentação básica ovimbundu) kapata (bebida de milho e de tubérculo silvestre, o mbundi), permitiu a absorção de 
elementos culturais ovimbundu, mas situados a um elevado nível da transculturação.

Todorov definiu quatro fases de compreensão do «outro»: a primeira fase, que consiste na assimilação do «outro» em si, da racionalização do próprio itinerário comercial, onde o conhecimento é enriquecido quantitativamente, porque há só uma identidade, a de Silva Porto (Idem: 38-39). A segunda, a fase de compreensão, consiste num apagamento de Silva Porto em benefício dos Ovimbundu. Renunciou muitas vezes a si próprio para se fundir com a cultura ovimbundu, sendo só uma emanação dela, em que há uma identidade ovimbundu. Na terceira fase voltou a assumir a sua identidade, mas depois de ter feito tudo para conhecer a sociedade ovimbundu, casou-se, gerou família e introduziu-a nos negócios, nas redes do tráfico e dos negócios confidenciais (Idem). ${ }^{19}$ Promoveu pombeiros, dignificou mulheres, serviçais, introduziu alimentos europeus. Por seu lado, absorveu dos africanos o infunde, a kisangwa e o lombi. $\mathrm{Na}$ terceira fase de exotopia exterioridade temporal espacial e cultural, produziu um novo conhecimento nos dois sentidos, qualitativo e quantitativo, a dualidade das culturas, multiplicidade que tomou lugar da unidade na qual Silva Porto permaneceu distinto da sociedade ovimbundu. Na quarta fase, a da compreensão dos Ovimbundu, retirou-se de si mesmo mas de forma diferente. Já não se identificava consigo mesmo nem com os Ovimbundu, esse movimento circundante é infinito, a sua identidade portuguesa manteve-se mas como se estivesse neutralizada. O espaço ovimbundu tornou-se um lugar de partilha e de compreensão possível entre ambos, pelas interacções, encontrava-se noutro lugar, não no objecto, mas no seu projecto de se tornar comerciante abastado. Todorov chama a nossa atenção para essas experiências humanas na sua infinidade diversificada, rescindindo os sentimentos intraduzíveis, especificidades incomunicáveis, e produzindo um esforço para sermos entendíveis, comunicativos de ser para ser, de cultura para cultura (Todorov 1992: 38-40).

19 Carta a sua filha em Bengela de 1 de Outubro de 1888. Silva Porto solicitava-lhe o envio de uma carta do codicilio para juntar ao testamento que havia guardado no fundo do baú da roupa, por não haver notário no Viyè, para que o mesmo testamento tivesse valor no caso «da minha morte antes de chegar aí». Esta filha, já com família constituída, era quem tratava dos negócios do pai em Bengela. 
Por fim, há uma interligação das variáveis de transculturação, que evoluíram desde o casamento, a base estratégica, conduzindo-o para as viagens que lhe deram a noção das rotas, do conhecimento do território, das relações socio-políticas e económicas, do contacto com o universo religioso bantu, e da alimentação para a necessidade biológica.

\section{Conclusão}

A transculturação de Silva Porto é, assim, avaliada no contexto das diferenças culturais da sociedade ovimbundu que o acolheu e a sociedade lusa e portuense por si representada, no cruzamento entre as duas culturas sob um processo de alteridade, ocorrida num contexto social definido na confluência do olhar distanciado, mas próximo do «outro», o ocimbundu, tal como claramente expressou: «[...] Tenciono ir a Portugal buscar minha filha, mas para regressar e continuar aqui a testa da minha obra quero morrer aqui, e eu ja disse em tempo que tinha três pátrias: Portugal, Brasil e África» (РоRто, Diário [Manuscrito], vol. II: 45). ${ }^{20}$

$\mathrm{E}$, finalmente, a síntese do trabalho que reflecte a problemática do processo da transculturação em Silva Porto no Viyè, na África central, decorrida na sociedade ovimbundu num confronto com a cultura europeia, a portuguesa. $\mathrm{O}$ estudo procurou analisar este processo, que se entendeu definir como a transculturação de Silva Porto, operada em cinco variáveis e dentre as quais ressaltamos o casamento poligínico, que foi a determinante fundamental para a sua inserção na cultura regional. A outra determinante, a comercial, é estruturada na base das viagens que efectuou para múltiplas zonas e regiões africanas, tal como se descreveu ao longo do nosso trabalho e se pode resumir no mapa referente às regiões de África central durante o século XIx, destacando-se aí o vasto Império Lunda, áreas de grande actuação socio-política e comercial, que se integraram no seu circuito de viagens de longo alcance, entre o interior e o litoral.

${ }^{20}$ Carta a Joaquim de Azevedo e Castro em 21 de Agosto de 1888. 
Figura 5. Este mapa representa o Reino Lunda em 1890, já amputado a Leste pelas possessões belgas; a Oeste e a Sul está o território português (futura Angola); o país Lozi (Barotze) ainda não se tinha transformado numa possessão britânica (é o território da futura Zâmbia)

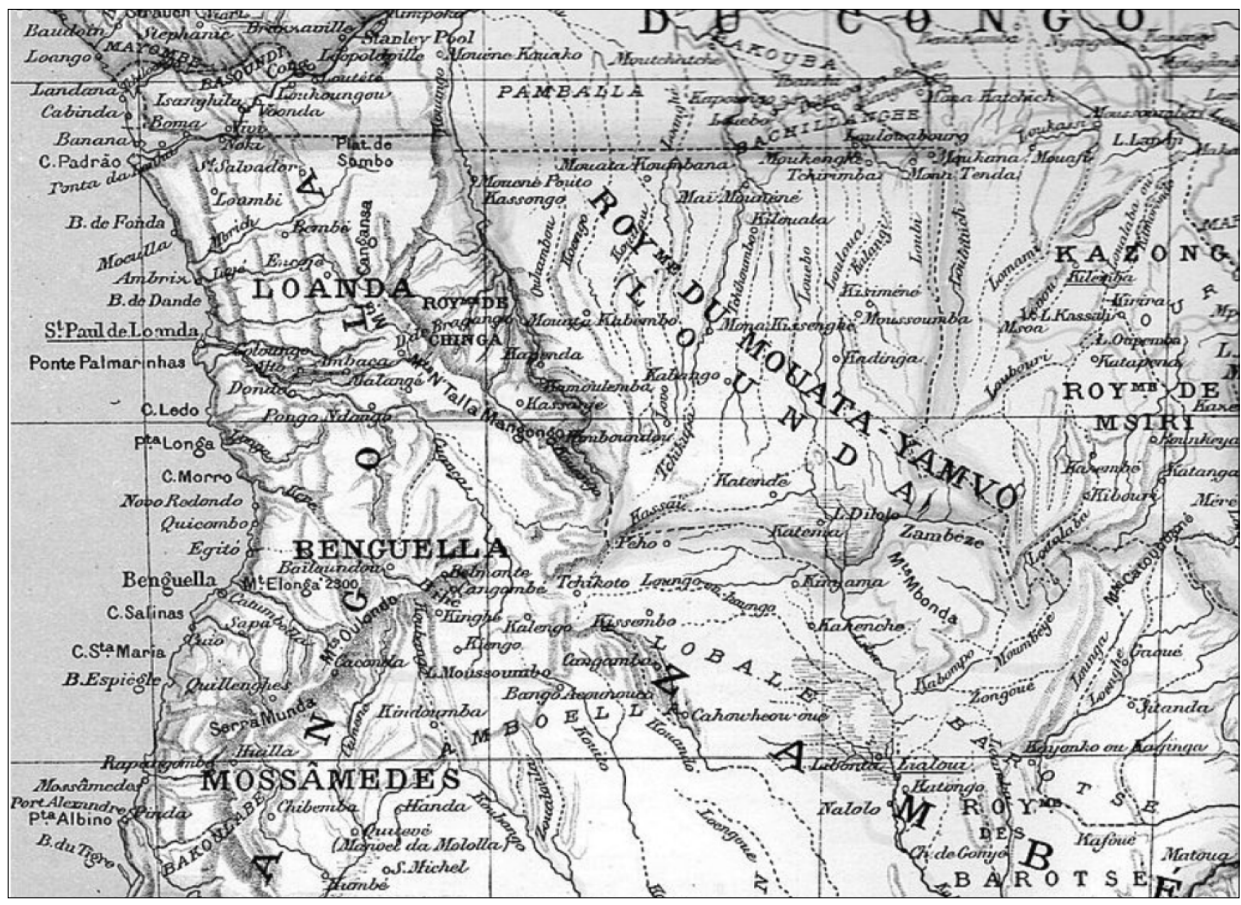

Fonte: <https://fr.wikipedia.org/wiki/Royaume_Lunda >

\section{Fontes de Arquivo e Referências bibliográficas}

\section{Fontes de Arquivo}

\section{1) Angola - Arquivo Histórico Nacional de Angola (AHNA)}

Carregadores:

Códices: 1679, 1829; 2118 2147, 2167, 2243, 2260, 2440

Citembo. Circunscrição do Alto Kwanza. Registo de Licenças, (1940): Códice: 3276/197 (10-3-8)

\section{- Bié}

Códices: 3052, 3053, 3054, 3055, 3057, 3058, 3059, 3060, 3061, 3063, 3067 
Avulsos: Pastas

Taxas registos do Bié: Circunscrição Civil (1903-1930)

Códices: 8 559, 8 872, 3 752, 8 852, 8 825, 8826

\section{- Benguela}

588, 641, 706, 707, 718, 737, 764, 766, 768, 769, 770, 773;

\section{- Benguela-a-Velha}

2303, 3065, 4062, 4082, 4087, 4089;

Núcleo Geral: G(5), 3-26 Bié. Comando de Destacamento militar. Correspondência expedida.1898.

\section{- Governo de Benguela}

Correspondência de Silva Porto ao Governador Coelho do Amaral, a Silva Porto.

\section{Biblioteca do Governo Provincial de Luanda}

Jornais

- O Sul de Angola (1856)

- O Jornal do Comércio de Angola (1889)

- O Comércio do Porto (1868-1890)

\section{- Governo do Distrito do Bié, Secretaria}

Silva Porto, Cidade Sede do Distrito e Sede do Concelho do Bié, fundado em 1766 (31 de Agosto, Diploma Legislativo 740, categoria de cidade de $3 \cdot{ }^{\mathrm{a}}$ classe, corpo administrativo e limites; Portaria 16. 613 de 27/12/69, Boletim Oficial, 301/69).

\section{2) República Democrática do Congo}

- Relatório de Silva Porto, Moçambique com o roteiro da viagem datado de 21 de Setembro de 1853.

- Le Mouvement Geographique, n. ${ }^{\circ}$ 23, 26, 2930

\section{3) República do Brasil}

- Arquivo de História Oral da Faculdade de Ciências Humanas, 
Centro de Pesquisa de Estudos e Intolerância, Migrações, da Universidade de São Paulo.

\section{4) Portugal}

\subsection{Biblioteca Pública Municipal do Porto}

- Sala de Reservados, Manuscrito, António Francisco Ferreira da Silva Porto, Viagens e Apontamentos de um Portuense em África, Cod. n. ${ }^{\circ} 1235$, vol. I.

PorTo António Francisco Ferreira da Silva, Copiador de Cartas (17 de Fevereiro de 1871 a 29 de Fevereiro de 1888), vol. 1. ${ }^{\circ}$ [Encadernado]. Res. Ms. 2-B-30.

- Manuscritos de Silva Porto

Porto, Viagens e Apontamentos de um Portuense em África.

Vol. 1. $^{\circ}$ (de 15 de Maio de 1846 a 30 de Abril de 1854)

Vol. $3 .^{\circ}$ (de 1 de Agosto de 1862 a 30 de Abril de 1866)

Vol. $3 .^{\circ}$ bis (de 1 de Janeiro de 1863 a 3 de Junho de 1864)

Vol. 11. ${ }^{\circ}$ (de 18 de Dezembro de 1884 a 15 de Julho de 1887)

Vol. $12^{\circ}$ (de 16 de Julho de 1887 a 31 de Outubro de 1889)

Cota: Res. Ms. 1235-1236.

\subsection{Arquivo Histórico Ultramarino (AHU)}

Relatório de Silva Porto (1884-1885-1886-1887)

Angola. Ndunduma - Prisão e deportação para Cabo Verde (Angola, 2. ${ }^{\text {a }}$ S., 1. ${ }^{\mathrm{a}}$ R., p. 11, Ofício de 21/2/1891)

Resposta de Silva Porto ao oficio n. ${ }^{\circ} 7$ de Março de 1852, do Governador de Moçambique, a partir do Lwi (Katonge)

\subsection{Biblioteca Nacional de Portugal}

Jornais:

- O Mundo Português (1899)

- O Ocidente (1934) 


\subsection{Biblioteca da Faculdade de Ciências Sociais e Hu- manas da Universidade Nova de Lisboa (B-FCSH-UNL)}

Jornais:

- O Mundo Português (1890, 1898, 1899)

- O Ocidente, Abril-Maio-Junho, vol. 1, n. ${ }^{\circ} 1$ (1878)-(1915)

- Público (Abril 2014)

Colecção Henrique de Carvalho, 1887. Centro de Redes em Investigação, Fundo Jill Rosemary Dias, Centro de História de Além-Mar.

\subsection{Biblioteca da Sociedade de Geografia de Lisboa (BSGL)}

Porto, Silva: Extractos da correspondência que tive com Domingos da Silva Porto relativa à escriptura de dissolução e arrendamento celebrada em 24 de Março de 1854. Lisboa, 1856. (Porbase)

Fundo dos Reservados, Pasta E, No $4-2,13$ de Agosto de 1841 a 26 de Dezembro de 1855. Caderno. Manuscrito. E Diário de Viagens de Silva Porto, Vol. XI.

Espólio de Silva Porto, Fundo dos reservados da B.S.G.L.

\subsection{Instituto dos Arquivos Nacionais da Torre do Tom- bo (IANTT)}

Despachos do Ministério da Marinha e Ultramar em resumo das actas constituintes de 1800 , por Decreto do Artigo $16^{\circ}$, do Boletim Oficial da Colónia n. ${ }^{\circ} 12$.

\section{Referências bibliográficas}

\section{Fontes impressas}

BANDEIRA Visconde de Sá da 1840, O tráfego da escravatura e o Bill de lord Palmerston. Lisboa, Typographia de José Baptista Morando. 
BRochado Bernardino José

1855, «Descripção das terras do Humbe, Camba, Mulondo, Quanhama, e outras [...] 1850», in Annaes do Conselho Ultramarino,

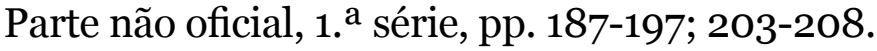

Capelo Hermenegildo e Ivens Roberto

1886, De Angola à contra costa. Lisboa, Imprensa Nacional.

1881, De Benguela às terras de Iácca: descripção de uma viagem na África Central e Ocidental. Lisboa, Imprensa Nacional, 2 volumes.

Carvalho Henrique de e Casanova Enrique

1890, Ethnographia e história tradicional dos povos da Lunda. Lisboa, Imprensa Nacional.

Chatelain Héli

1894, Folk-tales of Angola. Fifty tales, with Ki-mbundu text, literal English translation, introduction, and notes. Boston and New York, American Folk-lore Society by Houghton Mifflin and Company.

FERREIRA Francisco de Salles

1867, «Memória sobre o sertão de Cassanje», in Annaes do Conselho Ultramarino (Parte não oficial), Série 1 (Fev. 1854 - Dez. 1858). Lisboa, Imprensa Nacional, pp. 26-28.

FIDALGo José António

1889, «Relatório do Padre [...], missionário do Bihé e Bailundo (1887)», Annaes das Missões Portuguesas, Ano 2, pp. 154-58.

FonseCA José da

1840, Novo diccionário da língua portugueza recopilado de todos os que até o presente se tem teem dado à luz seguido de um dicionário completo dos synónymos portuguezes. Paris, J. P. Aillaud.

GraÇA Joaquim Rodrigues

1867, «Descripção da viagem feita de Loanda com destino às cabeceiras do Rio Sena», Annaes do Conselho Ultramarino (Parte não official), $1 .^{\mathrm{a}}$ série, p. 110.

1854, "Descripção da viagem feita de Loanda com destino às cabeceiras do Rio Sena», in Boletim Oficial de Angola, n. ${ }^{\circ}$ 446, pp. 451-456.

KRAPF J. L. e RAVENSTEIN E. G.

1860, Travels, researches, and missionary labours, during an eighteen years' residence in Eastern Africa: together with journeys to Jagga, Usambara, Ukambani, Shoa, Abessinia and Khartum, and a coasting voyage from Nombaz to Cape Delgado. Londres, Trübner and Co. 
Lima José Joaquim Lopes de

1844, Ensaios sobre a statistica das possessões Portuguezas na Africa Occidental e Oriental, na Asia Oriental, na China e na Oceania. Lisboa, Imprensa Nacional.

Livingston David et Charles 1881, Explorations du Zambèze et de des affluents et découverte des lacs Chiroua et Nyassa par David et Charles Livingstone: 1858-1864. Paris, Librairie Hachette.

Livingstone D. e VATTEMARE $\mathrm{H}$.

1886, David Livingston: voyages d'exploration au Zambèze et dans l'Afrique centrale, 1840-1873. Paris, Hachette.

MaGYar Ladislau

1856, «Carta ao governador de Benguela, sobre o interior da África Austral», Annaes do Conselho Ultramarino, Série 1. ${ }^{\mathrm{a}}$, pp. 237-240. 1849-1858, Viagens ao Interior de África [Manuscrito]. 1859, Reisen in Süd-Afrika in den Jahren 1849 bis 1857. Tradução de János Hunfalvy. Pest e Leipzig, Lauffer \& Stolp.

Magyar Amérigo Ladislau

1848, Viagens ao Interior de África aos reinos de Morupu. Budapeste, Zófia.

Neves António Rodrigues

1854, Memória da expedição a Cassange comandada pelo Major graduado Francisco de Salles Ferreira em 1850. Lisboa, Silvana.

NunEs Bernardo Joaquim e FidALGo José António 1889, «Relatório da viagem que os padres missionários [...] fizeram de Benguella ao Bihé, [1885]», in Annaes das Missões Ultramarinas, Ano 1, pp. 58-67

PaIva Artur de 1890, Expedição ao Cubango, 1889: Relatório. Lisboa, Imprensa Nacional.

PINTo Alexandre Serpa

1881, Como eu atravessei África: do Atlântico ao mar Índico, viagem de Benguella à contra-costa através de regiões desconhecidas, determinações geographicas e estudos ethnographicos. Londres, Sampson Low, Marston, Searle, e Rivington.

Porto António Francisco Ferreira da Silva

[s.d.] Viagens e apontamentos de um portuense em África: diário [Manuscrito].

SÁ da Bandeira Visconde de, ver Bandeira Visconde de Sá da, supra 


\section{Estudos}

ABREu Rodrigo

1947, Silva Porto na vida e na morte. Porto, Liga Portuguesa de Profilaxia Social, p. 6. [Separata de Portucale, Vol. III, 2. ${ }^{\mathrm{a}}$ série. Conferência realizada, a convite da Liga Portuguesa de Profilaxia Social, em 31 de Outubro de 1947].

Alves Jorge Fernandes

1993, Os brasileiros: emigração e retorno no Porto oitocentista, 2 volumes. Tese doutoramento em História Moderna e Contemporânea. Porto, Universidade do Porto.

Amaral Ilídio do e Amaral Ana

1948, «A viagem dos pombeiros angolanos Pedro João Baptista e Amaro José entre Mucari (Angola) e Tete (Moçambique), em princípios do século XIX, ou a história da primeira travessia da África central», Garcia de Orta, vol. 9, n. ${ }^{0}$ 1-2, pp. 17-57.

Augé Marc (ed.)

1978, Os domínios do parentesco: Fìliação, aliança matrimonial e residência. Lisboa, Edições 70.

Azevedo Domingos de 1984, Grande Dicionário Francês-Português. Lisboa, Bertrand.

BAL Willy 1965, «Portugais Pombeiro, comerçant ambulant du Sertão», Annali, vol. viI, n. ${ }^{\circ}$ 2, Julho.

BAPTISTA Pedro João e José Amaro 1960, Mensário Administrativo (Luanda), n. ${ }^{0}$ 155-160, Julho-Dezembro.

BASTIDE Roger

1972, «Lusotropicology, race and nationalism, and class protest and development in Brazil and Portuguese Africa», in Ronald $\mathrm{H}$. Chilcote (ed.), Protest and resistance in Angola and Brazil: comparative studies. Londres, Berkeley e Los Angeles, University of California Press, pp. 225-240.

Bastos Cristiana

2013, "Tesouros escondidos num pequeno artigo: "Famine and disease in the History of Angola (c.1830-1930)" de Jill R. Dias», in As Lições de Jill Dias: Antropologia, História, África, Academia. Lisboa, CRIA e FCG, pp. 222-228.

BENGUELA

1912, Limites do distrito de Benguela e suas divisões administrativas: aprovado por Portaria Provincial no 1062-E, de 16 de Setembro de 1912. Loanda, Imprensa Nacional. 
1910, Relatório da Missão de Colonização no Planalto de Benguella em 1909. Loanda, Imprensa Nacional, 1910.

BERTY Valérie

2001, Littérature et voyage au XIXe siècle: un essai de typologie narrative des récits de voyage français en Orient au XIxe siècle. Paris, L'Harmattan, 2001.

BIRMINGHAM David

1989, «O comércio sertanejo em Angola no século dezanove», $R e$ vista Internacional de Estudos Africanos (Lisboa), n. ${ }^{\circ}$ 10-11, pp. 283-288.

BLOCH Marc

1997, Introdução à História. Lisboa, Publicações Europa-América.

Bogumil Jewsiewicki; M’вокоlo Elikia; Ndaywel è Nziem; Kivilu Sabakinu (dir.)

1990, Moi, l'autre, nous autres: vies zaïroises ordinaires, 1930-1980. Dix récits. Prefácio de Nyango Mpeye. Paris: École des Hautes Études en Sciences Sociales; Centre d'Étude sur la Langue, les Arts et les Traditions Populaires des Francophones en Amérique du Nord; SAFI.

Bolota Abel Augusto B. C.

1967, Benguela cidade mãe das cidades. Benguela, Câmara Municipal.

BonTINCK François

1975, «Silva Porto: Journal d'un voyage transafricain, Bié (20 Novembre 1852) - Mozambique (8 Septembre 1854)», in Likundoli (Kinshasa), Presses Universitaires du Zaïre, vol. III, n. ${ }^{\circ}$ 1-2, pp. 5-133.

BOSSARD Eric

1985, Précis de parenté et son évolution chez les Ovimbundu. Neuchâtel, Université de Neuchâtel.

Butscu Helena e DuARTE João Ferreira (orgs.)

2001, Narrativas da modernidade: a construção do outro. Lisboa, Edições Colibri.

Ceita Constança da Rosa Fereira de 2001, A vida e a obra de Silva Porto no Reino Ovimbundu, Viyè (1839-1890). Dissertação de Mestrado em História Contemporânea. Porto, Universidade do Porto.

CHILDs Gladwyn Murray

1949, Umbundu kinship \& character: being a description of social structure and individual development of the Ovimbundu of Angola: with observations concerning the bearing on the enterprise of 
Christian missions of certain phases of the life and culture described. Londres e New York, Oxford University Press.

CORDEIRo Luciano

1890, Silva Porto. Lisboa, Comércio do Porto.

CURTo Diogo Ramada

2014, «Uma leitura ingénua da exploração portuguesa do continente», Público (Lisboa), 30 de Maio.

Daniel Henrique Etaungo

2002, Ondisionaliu Yumbundu; Dicionário de Umbundo: Umbundo-Português. Póvoa de Santo Adrião, Edições NAHO; Europress.

DiAs Gastão de Sousa

1938, Silva Porto e a travessia do continente africano. Lisboa, Agência Geral das Colónias.

DiAs Jill R.

1984, «Uma questão de identidade: respostas intelectuais às transformações económicas no seio da elite crioula da Angola portuguesa entre 1870 e 1930», Revista Internacional de Estudos Africanos, n. ${ }^{\circ}$ 1, pp. 61-94.

EDWARDS Adrian C.

1962, The Ovimbundu under two sovereignties. A study of social control and social change among a people of Angola. Londres, International African Institute.

FODOR István e MAGYAR László

1983, Introduction to the history of Umbundu: L. Magyar's records (1859) and the later sources. Hamburgo, H. Buske; Budapeste, Akadémia Kiadó.

GÉrAud Marie-Odile; LeservoIsIER Olivier e POITTIER Richard 2000, Les notions clés de l'ethnologie: analyses et textes. Paris, Armand Colin.

HAMBLY WiLFRID D.

1934, The Ovimbundu of Angola. Frederick H. Rawson-Field Museum Ethnological Expedition to Africa, 1929-30. Chicago, Field Museum of Natural History, Publication 329 [«Anthropological Series», vol. XXI, n. ${ }^{\circ}$ 2].

HAUENSTEIN Alfred

1983, «La royauté chez les Ovimbundu» in Angola, os símbolos do poder na sociedade tradicional. Coimbra, Centro de Estudos Africanos da Universidade de Coimbra, pp. 67-79.

HeINTZE Beatrix

2008, «Long-distance caravans and communication beyond the Kwango (c. 1850-1890)», in Beatrix Heintze e Achim von Oppen 
(eds.), Angola on the move: transport routes, communications and history/Angola em movimento: vias de transporte, comunicação e história. Frankfurt am Main, Verlag Otto Lembeck, pp. 144-162.

Henriques Isabel de Castro

1997, Percursos da modernidade em Angola: dinâmicas comerciais e transformações sociais no século XIX. Prefácio de Jean Devisse; tradução de Alfredo Margarido. Lisboa, Instituto de Investigação Científica Tropical; Instituto da Cooperação Portuguesa.

Heymann Luciana Quillet

2008, "Arquivos e interdisciplinaridade: algumas reflexões», in Seminário CPDOC 35 anos: A interdisciplinaridade nos estudos históricos. Rio de Janeiro. Disponível em <www.cpdoc.fgv.br >

IzNAGA Diana

1982, «Fernando Ortiz: La transculturación, concepto definitorio», in Bohemia (La Habana), n. ${ }^{\circ}$ 26, pp. 16-19.

1989, «Transculturación en Fernando Ortiz». La Habana, Editorial de Ciencias Sociales [«Ensayo»].

JERÓNIMO Miguel Bandeira

2009, Livros brancos, almas negras: a «missão civilizadora» do colonialismo português c. 1870-189o. Lisboa, Instituto de Ciências Sociais.

KILANI Mondher

1994, L’invention de l'autre: essais sur le discours anthropologique. Paris, Payot.

LEJEUne Philippe

1975, Le pacte autobiographique. Paris, Seuil.

LÉvi-Strauss Claude

1983, O olhar distanciado. Lisboa, Edições 70.

M'вокоцо Elikia

1977, L'ère des calamités: l'Afrique Australe au xixe et au xxe siècle. Paris, ABC.

Machado M. H. Pereira Toledo 2000, «Os olhos do Império. Relatos de viagem e transculturação», Revista Brasileira de História, vol. 20, n. ${ }^{0} 39$ pp. 281-289.

Malheiro Alexandre 1903, Chronicas do Bihé. Lisboa, Livraria Ferreira.

MaLINOWski Bronislaw

2002, «Introducción», in Fernando Ortiz, Contrapunteo Cubano del tabaco y el azúcar. Madrid, Cátedra [Wikipedia.org/Contrapunteo cubano del cubano del azúcar]. 
Malumbu Moisés

2005, Os Ovimbundu de Angola: tradição, economia e cultura organizativa. Prefácio de M. L. Rodrigues de Areia. Roma, Edizione Vivere In.

Meillassoux Claude

1986, Anthropologie de l'esclavage: le ventre de fer et d'argent. Paris, Presses Universitaires de France.

MichaRd Pierre e Yatchinovsky Arlette

1995, Histoire de vie: une nouvelle approche pour repenser sa vie autrement. Paris, ESF.

Miller Joseph Calder e Thornton John K.

1987, "The chronicle as source, history, and hagiography: The "Catálogo dos governadores de Angola” ", Paideuma, n. ${ }^{\circ}$ 33, pp. 359-89.

1990, «A crónica como fonte, história e hagiografia: O Catálogo dos Governadores de Angola», Revista Internacional de Estudos Africanos (Lisboa), n. ${ }^{\circ}$ 12-13, pp. 9-55.

Mwembu D. Dibwe dia

2004, «Le poids des sources orales dans l'écriture et la réécriture de l'histoire contemporaine au Katanga» in Pamphile Mabiala Mantuba-Ngoma (ed.), La nouvelle histoire du Congo: mélanges eurafricains offerts à Frans Bontinck. Paris, L'Harmattan; Tervuren, Koninklijk museum voor midden-Afrika; Musée Royal de l'Afrique Centrale, pp. 35-45.

Nora Pierre

1993, «Entre história e memória: a problemática dos lugares», $R e$ vista Projeto História (São Paulo), vol. 10, pp. 7-28.

ORTIZ Fernando

1983, «Del fenómeno de la "transcuturación” y de su importancia en Cuba», in Fernando Ortiz, El contrapunteo cubano del azúcar y del tabaco. La Habana, Editorial de Ciencias Sociales.

[s.d.], «Do fenômeno social da transculturação e sua importância em Cuba», tradução de Lívia Reis. Disponível em <www.ufrgs.br/ cdrom/ortiz/ortiz.pdf>

OWONO-NGUEMA François

1989, CICIBA - Facteurs cultureles et projets de développement rural en Afrique Centrale. Libreville, Centre Culturel des Civilisations Bantu.

PARK Mungo

2011, Travels in the interior districts of Africa. London, British Library, Historical Print Editions. 
PARREIRA Carlos

1945, O sertanejo do Bié (Silva Pôrto). Lisboa, Agência Geral das Colónias.

PetTitT Clare 2007, Dr. Livingstone, I presume?: missionaries, journalists, explorers, and empire. Cambridge, Mass., Harvard University Press.

PRATT Mary Louise

2008 (2. ${ }^{\mathrm{a}}$ edição), Imperial eyes: Travel writing and transculturation. Londres e New York, Routledge.

RADCLIFFE-BRown A. R. e Ford Daryll 1982, Sistemas políticos africanos de parentesco e casamento. Lisboa, Fundação Calouste Gulbenkian.

REDFIELD Robert; LinTON Ralph e HERsKovits Melville J. 1936, «Memorandum for the study of acculturation», American Anthropologist: Journal of the American Anthropological Association Beyond the frontier: social process and cultural change, vol. 38, n. ${ }^{\circ}$ 1, pp. 149-152.

Ricoeur Paul 1983-1985, Temps et récit. Paris, Seuil.

Rosa Delgado Frederico e VERde Filipe 2014, Exploradores portugueses e reis africanos. Viagens ao coração de África no século XIX (com a colaboração de Gustavo Rubim). Lisboa, Esfera dos Livros.

SANJUKILA Elias

2002, Reino do Bailundo: sua história na resistência tenaz contra o colonialismo português. Huambo, Direcção Provincial da Cultura do Huambo [policopiado].

SANTos Maria Emília Madeira 1986,Viagens e apontamentos de um portuense em África: diário de António Francisco Ferreira da Silva Porto. Coimbra, Biblioteca Geral da Universidade de Coimbra, 1986.

1981, Perspectiva do comércio sertanejo do Bié na segunda metade do século XIX. Lisboa, Junta de Investigação Científica do Ultramar.

Todorov Tzvetan

1982, La conquête de l'Amérique: la question de l'autre. Paris, Seuil.

VALENTIM Cristina Sá

2013, $O(s)$ pó(s) do arquivo. Uma etnografia em arquivo colonial, numa pesquisa pós-colonial. Iv Colóquio Internacional de 
Doutorandos(as) do CEs, 6-7 de Dezembro de 2013. Coimbra, Faculdade de Economia da Universidade de Coimbra. Disponível em <http://cabodostrabalhos.ces.uc.pt/n10/documentos/7.1.2_ Cristina_Sa_Valentim.pdf $>$

\title{
VANSINA Jan
}

1962, "Long-distance trade-routes in Central Africa», Journal of African History, vol. III, n. ${ }^{\circ}$ 3, pp. 375-390.

VELLUT Jean-Luc

1972, «Notes sur le Lunda et la frontière Luso-africaine (1700-1900)», in Études d'Histoire Áfricaine (Louvain), T. III, pp. 61-160.

Westbeech George; Macleod Norman e TABler Edward C. 1963, Trade and travel in early Barotseland: the diaries of George Westbeech, 1885-1888, and Captain Norman MacLeod, 1875-1876. Berkeley, University of California Press.

\author{
Recepção do manuscrito: 21/09/2015 \\ Conclusão da revisão: 16/10/2015 \\ Aceite para publicação em: 30/10/2015
}

Title: The transculturation of Silva Porto in Central Africa - Viyè - $19^{\text {th }}$ Century

\begin{abstract}
The study of the phenomenon of transculturation has found a vast field of analysis in Central Africa. According to Fernando Ortiz, transculturation is a phenomenon understood as the transition from one culture to another, with the loss or partial disconnection of the preceding culture. It is on the basis of such assumptions that the Cuban social scientist formulates a theoretical basis on the transculturation that occurs between various cultures arising from the social environment. With the present work, we seek to situate our research in the context of the processes resulting from the interlacing between various interacting cultures, in the historical and sociocultural environment Ovimbundu, in the Central Plateau of Angola, in a spatial context of Central Africa. Due to the various contacts established there, this cultural diversity gave rise to multiple identities. The studied transculturation phenomenon developed in the second quarter of 19 th century. The complexity and scope of this work led to an approach centered on the biographical history of the Portuguese António Francisco Ferreira da Silva Porto - a person who became better known to Silva Porto (1839-1890) - with particular emphasis on his involvement in the socio-cultural milieu Ovimbundu. In this article, we try to analyze the socio-cultural interaction between the sertanejo and the ovimbundu society, highlighting the intercultural relationship, the history of social and transcultural relations between the latter and the society that welcomed him in 1839. This intercultural relationship has constituted an important «contact zone», which we consider very precisely as the zone of socio-political, economic and cultural coexistence. To this end, the historian Mary Pratt, who reflected and innovated on the term «contact zones», defined it as social spaces where different cultures meet, collide and learn to deal with one another, most of the times in asymmetric relationships. Accordingly, the synthesis of our work reflects the problem of a transculturation process that took place specifically in the Ombimbundu society in Angola and, generally, in Central Africa, as a result of the confrontation between European culture and African culture, particularly Portuguese and Ovimbundu. Finally, it is a historical-anthropological study articulated mainly from four variables: polygynic marriage, food, commerce and religion,
\end{abstract}


variables that, in our opinion, would determine the transculturation of the Portuguese sertanejo in the Central Africa.

Keywords: Fernando Ortiz, transculturation, acculturation, zones of intercultural contact, sertanejo commerce, ovimbundu society, umbundu language, Angola, Central Africa, Southern Africa, António Francisco Ferreira da Silva Porto.

\section{Constança do Nascimento da Rosa Ferreira de Ceita}

É Professora Auxiliar do Departamento de História (DH) da Faculdade de Ciências Sociais (FCS) da Universidade Agostinho Neto (UAN) onde, no âmbito do curso de História, lecciona as cadeiras de História de Angola, História de África, História política, económica e social de Angola. Doutorada em Estudos Africanos (2015) na especialidade Estudos de Cultura pela Universidade Nova de Lisboa, onde submeteu o trabalho intitulado História social e transcultural de Silva Porto na África Central, 1840-1930; mestre em História de África (2001), pela Faculdade de Letras da Universidade do Porto, onde submeteu a seguinte dissertação: A vida e obra de Silva Porto em África, Angola, Viyè, 1838-189o e licenciada em Ensino da História pelo Instituto Superior de Ciências da Educação (ISCED) de Luanda (1995), onde submeteu o trabalho intitulado A função educativa dos Museus: o caso da rede museológica de Luanda. Possui as seguintes especializações: Ética em investigação científica pela Universidade Nova de Lisboa, Portugal (2015); História biográfica, pelo ISCTE - Instituto Superior de Ciências do Trabalho e da Empresa, Lisboa, Portugal (2012); Pós-graduação em História Oral, pelo Instituto de História Oral, Universidade de São Paulo, República Federativa do Brasil (2011).

Participou em conferências e colóquios, onde submeteu os textos seguintes: $O$ tráfico de escravos no transatlântico a partir da região leste de Angola, Universidade Presbetiana, São Paulo, Brasil (2015); A batalha de Mbwila e suas repercussões na África Central, comunicação apresentada no I Colóquio Internacional sobre Kimpa Vita: entre memória e história, de 2 a 4 de Julho de 2014, Uíje, Universidade Kimpa Vita (2014); A transculturação no contexto da imigração entre África, América e Europa no século XIX, Instituto de História Oral, Universidade de São Paulo (2012); Kitawala et ses implications sociales en Angola, comunicação apresentada na Conferência Internacional sobre Simon Kimbangu: son oeuvre, pour la libertion de l'Afrique Noir, Université Simon Kimbangu, Kinshasa, RDC (2012); Dona Ana Joaquina: tentativa de um ensaio biográfico, conferência apresentada nas Jornadas Científicas da Faculdade de Ciências Sociais da Universidade Agostinho Neto (2012); A importância das fontes para a História de Angola, Faculdade de Ciências Sociais da Universidade Agostinho Neto (2010); «De escravos a serviçais ou contratados em Angola no século XIX, em Angola no século XIX», in 
Actas do III Encontro Internacional de História de Angola. Luanda, Arquivo Histórico Nacional de Angola, pp. 169-185 (2007); A escravatura na óptica e liderança de Silva Porto na África Central e Austral (1840-1930), Centro de Estudos Africanos da Universidade do Porto (2006); Viagens de exploração científica em África no século XIX e suas implicações sociopolíticas no contexto da SADC, Universidade Jean Piaget, Luanda (2005).

[e-mail: cons.ceita12@gmail.com] 